\title{
Adrenoceptors (version 2019.4) in the IUPHAR/BPS Guide to Pharmacology Database
}

\author{
Katrin Altosaar ${ }^{1}$, Poornima Balaji2, Richard A. Bond ${ }^{3}$, David B. Bylund ${ }^{4}$, Susanna Cotecchia ${ }^{5}$, Dominic Devost ${ }^{6}$, \\ Van A. Doze ${ }^{7}$, Douglas C. Eikenburg ${ }^{8}$, Sarah Gora ${ }^{6}$, Eugénie Goupi ${ }^{6}$, Robert M. Graham², Terry Hébert ${ }^{6}$, J. \\ Paul Hieble ${ }^{9}$, Rebecca Hills ${ }^{10}$, Shahriar Kan ${ }^{6}$, Gayane Machkalyan ${ }^{6}$, Martin C. Michel ${ }^{11}$, Kenneth P. \\ Minneman ${ }^{12}$, Sergio Parra ${ }^{3}$, Dianne Perez ${ }^{13}$, Rory Sleno ${ }^{6}$, Roger Summers ${ }^{14}$ and Peter Zylbergold 6 \\ 1. Boehringer Laboratories, LLC, USA \\ 2. Victor Chang Cardiac Research Institute, Australia \\ 3. University of Houston, USA \\ 4. University of Nebraska, USA \\ 5. Université de Lausanne, Switzerland \\ 6. McGill University, Canada \\ 7. University of North Dakota, USA \\ 8. University of Houston College of Pharmacy, USA \\ 9. GlaxoSmithKline, USA \\ 10. University of Edinburgh, UK \\ 11. Johannes Gutenberg University, Germany \\ 12. Emory University, USA \\ 13. Cleveland Clinic Lerner Research Institute, USA \\ 14. Monash University, Australia
}

\section{Abstract}

The nomenclature of the Adrenoceptors has been agreed by theNC-IUPHAR Subcommittee on Adrenoceptors [58], see also [180].

\section{Adrenoceptors, $\alpha_{1}$}

$\alpha_{1}$-Adrenoceptors are activated by the endogenous agonists(-)-adrenaline and (-)-noradrenaline.

phenylephrine, methoxamine and cirazoline are agonists and prazosin and cirazoline antagonists considered selective for $\alpha_{1}$ - relative to $\alpha_{2}$-adrenoceptors. [ ${ }^{3} \mathrm{H}$ ]prazosin and [ $\left.{ }^{125} \mathrm{I}\right] \mathrm{HEAT}$ (BE2254) are relatively selective radioligands. $\mathrm{S}(+)$-niguldipine also has high affinity for $\mathrm{L}$-type $\mathrm{Ca}^{2+}$ channels. Fluorescent derivatives of prazosin (Bodipy PLprazosin- QAPB) are used to examine cellular localisation of $\alpha_{1}$-adrenoceptors. Selective $\alpha_{1}$ adrenoceptor agonists are used as nasal decongestants; antagonists to treat hypertension (doxazosin, prazosin) and benign prostatic hyperplasia (alfuzosin, tamsulosin). The $\alpha_{1}$ - and $\beta_{2}$-adrenoceptor antagonist carvedilol is used to treat congestive heart failure, although the contribution of $\alpha_{1}$-adrenoceptor blockade to the therapeutic effect is unclear. Several anti-depressants and anti-psychotic drugs are $\alpha_{1}$-adrenoceptor antagonists contributing to side effects such as orthostatic hypotension and extrapyramidal effects. 


\section{Adrenoceptors, $\alpha_{2}$}

$\alpha_{2}$-Adrenoceptors are activated by (-)-adrenaline and with lower potency by (-)-noradrenaline. brimonidine and talipexole are agonists and rauwolscine and yohimbine antagonists selective for $\alpha_{2}$ - relative to $\alpha_{1}$ -

adrenoceptors. $\left[{ }^{3} \mathrm{H}\right]$ rauwolscine, $\left[{ }^{3} \mathrm{H}\right]$ brimonidine and $\left[{ }^{3} \mathrm{H}\right] \mathrm{R} X 821002$ are relatively selective radioligands. There is species variation in the pharmacology of the $\alpha_{2 A}$-adrenoceptor. Multiple mutations of $\alpha_{2}$-adrenoceptors have been described, some associated with alterations in function. Presynaptic $\alpha_{2}$-adrenoceptors regulate many functions in the nervous system. The $\alpha_{2}$-adrenoceptor agonists clonidine, guanabenz and brimonidine affect central baroreflex control (hypotension and bradycardia), induce hypnotic effects and analgesia, and modulate seizure activity and platelet aggregation. clonidine is an anti-hypertensive and counteracts opioid withdrawal. dexmedetomidine (also xylazine) is used as a sedative and analgesic in human and veterinary medicine with sympatholytic and anxiolytic properties. The $\alpha_{2}$-adrenoceptor antagonist yohimbine has been used to treat erectile dysfunction and mirtazapine as an anti-depressant. The $\alpha_{2 B}$ subtype appears to be involved in neurotransmission in the spinal cord and $\alpha_{2 C}$ in regulating catecholamine release from adrenal chromaffin cells.

\section{Adrenoceptors, $\beta$}

$\beta$-Adrenoceptors are activated by the endogenous agonists(-)-adrenaline and (-)-noradrenaline. Isoprenaline is selective for $\beta$-adrenoceptors relative to $\alpha_{1}$ - and $\alpha_{2}$-adrenoceptors, while propranolol ( $p K_{\mathrm{i}}$ 8.2-9.2) and cyanopindolol ( $\mathrm{p} K_{\mathrm{i}}$ 10.0-11.0) are relatively $\beta_{1}$ and $\beta_{2}$ adrenoceptor-selective antagonists. (-)-noradrenaline, xamoterol and (-)-Ro 363 show selectivity for $\beta_{1}$ - relative to $\beta_{2}$-adrenoceptors. Pharmacological differences exist between human and mouse $\beta_{3}$-adrenoceptors, and the 'rodent selective' agonists BRL 37344 and CL316243 have low efficacy at the human $\beta_{3}$-adrenoceptor whereas CGP 12177 and $L 755507$ activate human $\beta_{3^{-}}$ adrenoceptors [88]. $\beta_{3}$-Adrenoceptors are resistant to blockade bypropranolol, but can be blocked by high concentrations of bupranolol. SR59230A has reasonably high affinity at $\beta_{3}$-adrenoceptors, but does not discriminate well between the three $\beta$ - subtypes whereas $L 755507$ is more selective. [ $\left.{ }^{125} \mid\right]$-cyanopindolol, $\left[{ }^{125} \mid\right]$ hydroxy benzylpindolol and $\left[{ }^{3} \mathrm{H}\right]$-alprenolol are high affinity radioligands that label $\beta_{1}$ - and $\beta_{2}$-adrenoceptors and $\beta_{3}$-adrenoceptors can be labelled with higher concentrations $(n M)$ of $\left[{ }^{25} \mathrm{l}\right]$-cyanopindolol together with $\beta_{1}$ - and $\beta_{2}$-adrenoceptor antagonists. $\left[\mathrm{H} \mathrm{H}\right.$-L-748337 is a $\beta_{3}$-selective radioligand [474]. Fluorescent ligands such as BODIPY-TMR-CGP12177 can be used to track $\beta$-adrenoceptors at the cellular level [8]. Somewhat selective $\beta_{1^{-}}$ adrenoceptor agonists (denopamine, dobutamine) are used short term to treat cardiogenic shock but, chronically, reduce survival. $\beta_{1}$-Adrenoceptor-preferring antagonists are used to treat hypertension fatenolol, betaxolol, bisoprolol, metoprolol and nebivolol), cardiac arrhythmias (atenolol, bisoprolol, esmolol) and cardiac failure (metoprolol, nebivolol). Cardiac failure is also treated with carvedilol that blocks $\beta_{1}$ - and $\beta_{2}{ }^{-}$ adrenoceptors, as well as $\alpha_{1}$-adrenoceptors. Short (salbutamol, terbutaline) and long (formoterol, salmeterol) acting $\beta_{2}$-adrenoceptor-selective agonists are powerful bronchodilators used to treat respiratory disorders. Many first generation $\beta$-adrenoceptor antagonists (propranolol) block both $\beta_{1}$ - and $\beta_{2}$-adrenoceptors and there are no $\beta_{2}$-adrenoceptor-selective antagonists used therapeutically. The $\beta_{3}$-adrenoceptor agonist mirabegron is used to control overactive bladder syndrome.

\section{Contents}

This is a citation summary for Adrenoceptors in the Guide to Pharmacology database (GtoPdb). It exists purely as an adjunct to the database to facilitate the recognition of citations to and from the database by citation analyzers. Readers will almost certainly want to visit the relevant sections of the database which are given here under database links.

GtoPdb is an expert-driven guide to pharmacological targets and the substances that act on them. GtoPdb is a reference work which is most usefully represented as an on-line database. As in any publication this work 
should be appropriately cited, and the papers it cites should also be recognized. This document provides a citation for the relevant parts of the database, and also provides a reference list for the research cited by those parts.

Please note that the database version for the citations given in GtoPdb are to the most recent preceding version in which the family or its subfamilies and targets were substantially changed. The links below are to the current version. If you need to consult the cited version, rather than the most recent version, please contact the GtoPdb curators.

\section{Database links}

\section{Adrenoceptors}

http://www.guidetopharmacology.org/GRAC/FamilyDisplayForward?familyld=4 Introduction to Adrenoceptors

http://www.guidetopharmacology.org/GRAC/FamilyIntroductionForward?familyld=4

Receptors

$$
\begin{aligned}
& \alpha_{1 A^{-}} \text {-adrenoceptor } \\
& \text { http://www.guidetopharmacology.org/GRAC/ObjectDisplayForward?objectld=22 } \\
& \alpha_{1 B^{-}} \text {-adrenoceptor } \\
& \text { http://www.guidetopharmacology.org/GRAC/ObjectDisplayForward?objectld=23 } \\
& \alpha_{1 D} \text {-adrenoceptor } \\
& \text { http://www.guidetopharmacology.org/GRAC/ObjectDisplayForward?objectld=24 } \\
& \alpha_{2 A} \text {-adrenoceptor } \\
& \text { http://www.guidetopharmacology.org/GRAC/ObjectDisplayForward?objectld=25 } \\
& \alpha_{2 B} \text {-adrenoceptor } \\
& \text { http://www.guidetopharmacology.org/GRAC/ObjectDisplayForward?objectld=26 } \\
& \alpha_{2 C} \text {-adrenoceptor } \\
& \text { http://www.guidetopharmacology.org/GRAC/ObjectDisplayForward?objectld=27 } \\
& \beta_{1} \text {-adrenoceptor } \\
& \text { http://www.guidetopharmacology.org/GRAC/ObjectDisplayForward?objectld=28 } \\
& \beta_{2} \text {-adrenoceptor } \\
& \text { http://www.guidetopharmacology.org/GRAC/ObjectDisplayForward?objectld=29 } \\
& \beta_{3} \text {-adrenoceptor } \\
& \text { http://www.guidetopharmacology.org/GRAC/ObjectDisplayForward?objectld=30 }
\end{aligned}
$$

\section{References}

1. Abdulla MH, Sattar MA, Johns EJ, Abdullah NA, Hye Khan MA and Rathore HA. (2012) High-fructose feeding impacts on the adrenergic control of renal haemodynamics in the rat. Br. J. Nutr. 107: 218-28 [PMID:21733307]

2. Abraham G, Kneuer C, Ehrhardt C, Honscha W and Ungemach FR. (2004) Expression of functional beta2adrenergic receptors in the lung epithelial cell lines 16HBE140(-), Calu-3 and A549. Biochim. Biophys. Acta 1691: 169-79 [PMID:15110997]

3. Acosta-Martinez M, Fiber JM, Brown RD and Etgen AM. (1999) Localization of alpha1B-adrenergic receptor in female rat brain regions involved in stress and neuroendocrine function. Neurochemistry International 35: 383-391 [PMID:10517699]

4. Ahlquist RP. (1948) A study of adrenotropic receptors. Am. J. Physiol. 153: 586-600

5. Alikhani V, Beer D, Bentley D, Bruce I, Cuenoud BM, Fairhurst RA, Gedeck P, Haberthuer S, Hayden C and Janus $D$ et al.. (2004) Long-chain formoterol analogues: an investigation into the effect of increasing amino-substituent chain length on the beta2-adrenoceptor activity. Bioorg. Med. Chem. Lett. 14: 4705-10 
[PMID:15324892]

6. Allen JM, Baetge EE, Abrass IB and Palmiter RD. (1988) Isoproterenol response following transfection of the mouse beta 2-adrenergic receptor gene into Y1 cells. EMBO J. 7: 133-8 [PMID:2834198]

7. Alonso-Llamazares A, Zamanillo D, Casanova E, Ovalle S, Calvo P and Chinchetru MA. (1995) Molecular cloning of alpha $1 \mathrm{~d}$-adrenergic receptor and tissue distribution of three alpha 1-adrenergic receptor subtypes in mouse. J Neurochem 65: 2387-2392 [PMID:7595531]

8. Altman JD, Trendelenburg AU, MacMillan L, Bernstein D, Limbird L, Starke K, Kobilka BK and Hein L. (1999) Abnormal regulation of the sympathetic nervous system in alpha2A-adrenergic receptor knockout mice. Mol. Pharmacol. 56: 154-61 [PMID:10385696]

9. Amirahmadi F, Turnbull L, Du XJ, Graham RM and Woodcock EA. (2008) Heightened alpha1A-adrenergic receptor activity suppresses ischaemia/reperfusion-induced Ins $(1,4,5) \mathrm{P} 3$ generation in the mouse heart: a comparison with ischaemic preconditioning. Clin. Sci. 114: 157-64 [PMID:17696883]

10. Amirak E, Fuller SJ, Sugden PH and Clerk A. (2013) p90 ribosomal S6 kinases play a significant role in early gene regulation in the cardiomyocyte response to $G(q)$-protein-coupled receptor stimuli, endothelin-1 and $\alpha(1)$-adrenergic receptor agonists. Biochem. J. 450: 351-63 [PMID:23215897]

11. André C, Erraji L, Gaston J, Grimber G, Briand P and Guillet JG. (1996) Transgenic mice carrying the human beta 2-adrenergic receptor gene with its own promoter overexpress beta 2-adrenergic receptors in liver. Eur. J. Biochem. 241: 417-24 [PMID:8917438]

12. Angers S, Salahpour A, Joly E, Hilairet S, Chelsky D, Dennis M and Bouvier M. (2000) Detection of beta 2-adrenergic receptor dimerization in living cells using bioluminescence resonance energy transfer (BRET). Proc. Natl. Acad. Sci. U.S.A. 97: 3684-9 [PMID:10725388]

13. Aparici M, Gómez-Angelats M, Vilella D, Otal R, Carcasona C, Viñals M, Ramos I, Gavaldà A, De Alba J and Gras J et al.. (2012) Pharmacological characterization of abediterol, a novel inhaled $\beta$ (2)-adrenoceptor agonist with long duration of action and a favorable safety profile in preclinical models. J. Pharmacol. Exp. Ther. 342: 497-509 [PMID:22588259]

14. Arch JR, Ainsworth AT, Cawthorne MA, Piercy V, Sennitt MV, Thody VE, Wilson C and Wilson S. (1984) Atypical beta-adrenoceptor on brown adipocytes as target for anti-obesity drugs. Nature 309: 163-5 [PMID:6325935]

15. Aristotelous T, Ahn S, Shukla AK, Gawron S, Sassano MF, Kahsai AW, Wingler LM, Zhu X, TripathiShukla P and Huang XP et al.. (2013) Discovery of $\beta 2$ Adrenergic Receptor Ligands Using Biosensor Fragment Screening of Tagged Wild-Type Receptor. ACS Med Chem Lett 4: 1005-1010 [PMID:24454993]

16. Armenia, Sattar MA, Abdullah NA, Khan MA and Johns EJ. (2008) Alpha1A- and alpha1D-adrenoceptors are the major functional subtypes of renal alpha1-adrenoceptors in streptozotocin-induced diabetic and normal Sprague-Dawley rats. Auton Autacoid Pharmaco/ 28: 1-10 [PMID:18257746]

17. Aroniadou-Anderjaska V, Qashu F and Braga MF. (2007) Mechanisms regulating GABAergic inhibitory transmission in the basolateral amygdala: implications for epilepsy and anxiety disorders. Amino Acids $\mathbf{3 2}$ : 305-15 [PMID:17048126]

18. Arévalo-León LE, Gallardo-Ortíz IA, Urquiza-Marín H and Villalobos-Molina R. (2003) Evidence for the role of alpha1D- and alpha1A-adrenoceptors in contraction of the rat mesenteric artery. Vascul. Pharmacol. 40: 91-6 [PMID:12646397]

19. Auclair A, Drouin C, Cotecchia S, Glowinski J and Tassin JP. (2004) 5-HT2A and alpha1b-adrenergic receptors entirely mediate dopamine release, locomotor response and behavioural sensitization to opiates and psychostimulants. Eur. J. Neurosci. 20: 3073-84 [PMID:15579162]

20. Auerbach SS and DrugMatrix $\AA$ and ToxFX $\AA$ Coordinator National Toxicology Program.. National Toxicology Program: Dept of Health and Human Services.

21. Baerwald C, Graefe C, Muhl C, Von Wichert P and Krause A. (1992) Beta 2-adrenergic receptors on peripheral blood mononuclear cells in patients with rheumatic diseases. Eur. J. Clin. Invest. 22 Suppl 1: 42-6 [PMID:1333966]

22. Baker JG. (2005) The selectivity of beta-adrenoceptor antagonists at the human beta1, beta2 and beta3 adrenoceptors. Br. J. Pharmacol. 144: 317-22 [PMID:15655528] 
23. Baker JG. (2010) The selectivity of beta-adrenoceptor agonists at human beta1-, beta2- and beta3adrenoceptors. Br. J. Pharmacol. 160: 1048-61 [PMID:20590599]

24. Baker JG. (2010) A full pharmacological analysis of the three turkey $\beta$-adrenoceptors and comparison with the human $\beta$-adrenoceptors. PLoS ONE 5: e15487 [PMID:21152092]

25. Baker JG, Hall IP and Hill SJ. (2003) Influence of agonist efficacy and receptor phosphorylation on antagonist affinity measurements: differences between second messenger and reporter gene responses. Mol. Pharmacol. 64: 679-88 [PMID:12920204]

26. Baker JG, Hall IP and Hill SJ. (2003) Agonist and inverse agonist actions of beta-blockers at the human beta 2-adrenoceptor provide evidence for agonist-directed signaling. Mol. Pharmacol. 64: 1357-69 [PMID:14645666]

27. Baker JG, Hall IP and Hill SJ. (2003) Pharmacology and direct visualisation of BODIPY-TMR-CGP: a longacting fluorescent beta2-adrenoceptor agonist. Br. J. Pharmacol. 139: 232-42 [PMID:12770928]

28. Baker JG, Hall IP and Hill SJ. (2002) Pharmacological characterization of CGP 12177 at the human beta(2)-adrenoceptor. Br. J. Pharmacol. 137: 400-8 [PMID:12237261]

29. Banie L, Lin G, Ning H, Wang G, Lue TF and Lin CS. (2008) Effects of estrogen, raloxifene and levormeloxifene on alpha1A-adrenergic receptor expression. J. Urol. 180: 2241-6 [PMID:18804812]

30. Bardou M, Dousset B, Deneux-Tharaux C, Smadja C, Naline E, Chaput JC, Naveau S, Manara L, Croci T and Advenier C. (1998) In vitro inhibition of human colonic motility with SR 59119A and SR 59104A: evidence of a beta3-adrenoceptor-mediated effect. Eur. J. Pharmacol. 353: 281-7 [PMID:9726658]

31. Barki-Harrington L, Luttrell LM and Rockman HA. (2003) Dual inhibition of beta-adrenergic and angiotensin II receptors by a single antagonist: a functional role for receptor-receptor interaction in vivo. Circulation 108: 1611-8 [PMID:12963634]

32. Battaglia G, Fornai F, Busceti CL, Lembo G, Nicoletti F and De Blasi A. (2003) Alpha-1B adrenergic receptor knockout mice are protected against methamphetamine toxicity. J. Neurochem. 86: 413-21 [PMID:12871582]

33. Battaglia G, Shannon M, Borgundvaag B and Titeler M. (1983) Properties of [3H]prazosin-labeled alpha 1adrenergic receptors in rat brain and porcine neurointermediate lobe tissue. J. Neurochem. 41: 538-42 [PMID:6308163]

34. Beattie D, Beer D, Bradley ME, Bruce I, Charlton SJ, Cuenoud BM, Fairhurst RA, Farr D, Fozard JR and Janus $D$ et al.. (2012) An investigation into the structure-activity relationships associated with the systematic modification of the $\beta$ (2)-adrenoceptor agonist indacaterol. Bioorg. Med. Chem. Lett. 22: 6280-5 [PMID:22932315]

35. Beattie D, Bradley M, Brearley A, Charlton SJ, Cuenoud BM, Fairhurst RA, Gedeck P, Gosling M, Janus D and Jones $D$ et al.. (2010) A physical properties based approach for the exploration of a 4hydroxybenzothiazolone series of beta2-adrenoceptor agonists as inhaled long-acting bronchodilators. Bioorg. Med. Chem. Lett. 20: 5302-7 [PMID:20655218]

36. Berkowitz DE, Nardone NA, Smiley RM, Price DT, Kreutter DK, Fremeau RT and Schwinn DA. (1995) Distribution of beta 3-adrenoceptor mRNA in human tissues. Eur J Pharmacol. 289: 223-228 [PMID:7621895]

37. Berthouze M, Ayoub M, Russo O, Rivail L, Sicsic S, Fischmeister R, Berque-Bestel I, Jockers R and Lezoualc'h F. (2005) Constitutive dimerization of human serotonin 5-HT4 receptors in living cells. FEBS Lett. 579: 2973-80 [PMID:15896782]

38. Bilezikian JP. (1987) Defining the Role of Adrenergic Receptors in Human Physiology.In Adrenergic Receptors in Man Edited by Insel PA: Marcel Dekker: 37-68 [ISBN: 0824776291]

39. Blaxall HS, Hass NA and Bylund DB. (1994) Expression of alpha 2-adrenergic receptor genes in rat tissues. Receptor 4: 191-9 [PMID:7812219]

40. Blaxall HS, Murphy TJ, Baker JC, Ray C and Bylund DB. (1991) Characterization of the alpha-2C adrenergic receptor subtype in the opossum kidney and in the OK cell line. J. Pharmacol. Exp. Ther. 259: 323-9 [PMID:1656026]

41. Blin N, Camoin L, Maigret B and Strosberg AD. (1993) Structural and conformational features determining 
selective signal transduction in the beta 3-adrenergic receptor. Mol. Pharmacol. 44: 1094-104

[PMID:7903415]

42. Blin N, Nahmias C, Drumare MF and Strosberg AD. (1994) Mediation of most atypical effects by species homologues of the beta 3-adrenoceptor. Br. J. Pharmacol. 112: 911-9 [PMID:7921620]

43. Blue DR, Daniels DV, Gever JR, Jett MF, O'Yang C, Tang HM, Williams TJ and Ford AP. (2004) Pharmacological characteristics of Ro 115-1240, a selective alpha1A/1L-adrenoceptor partial agonist: a potential therapy for stress urinary incontinence. BJU Int. 93: 162-70 [PMID:14678390]

44. Bokoch MP, Zou Y, Rasmussen SG, Liu CW, Nygaard R, Rosenbaum DM, Fung JJ, Choi HJ, Thian FS and Kobilka TS et al.. (2010) Ligand-specific regulation of the extracellular surface of a G-protein-coupled receptor. Nature 463: 108-12 [PMID:20054398]

45. Bolaños B and Mitchell TG. (1989) Phagocytosis and killing of Cryptococcus neoformans by rat alveolar macrophages in the absence of serum. J. Leukoc. Biol. 46: 521-8 [PMID:2681492]

46. Bond RA and Clarke DE. (1988) Agonist and antagonist characterization of a putative adrenoceptor with distinct pharmacological properties from the alpha- and beta-subtypes. Br. J. Pharmacol. 95: 723-734 [PMID:2905184]

47. Bouyssou T, Casarosa P, Naline E, Pestel S, Konetzki I, Devillier P and Schnapp A. (2010) Pharmacological characterization of olodaterol, a novel inhaled beta2-adrenoceptor agonist exerting a 24hour-long duration of action in preclinical models. J. Pharmacol. Exp. Ther. 334: 53-62 [PMID:20371707]

48. Breit A, Lagacé M and Bouvier M. (2004) Hetero-oligomerization between beta2- and beta3-adrenergic receptors generates a beta-adrenergic signaling unit with distinct functional properties. J. Biol. Chem. 279: 28756-65 [PMID:15123695]

49. Bristow MR, Hershberger RE, Port JD, Minobe W and Rasmussen R. (1989) Beta 1- and beta 2adrenergic receptor-mediated adenylate cyclase stimulation in nonfailing and failing human ventricular myocardium. Mol. Pharmacol. 35: 295-303 [PMID:2564629]

50. Brixius K, Bloch W, Pott C, Napp A, Krahwinkel A, Ziskoven C, Koriller M, Mehlhorn U, Hescheler J and Fleischmann B et al.. (2004) Mechanisms of beta 3-adrenoceptor-induced eNOS activation in right atrial and left ventricular human myocardium. Br. J. Pharmacol. 143: 1014-22 [PMID:15466444]

51. Brown DA and Dunn PM. (1983) Depolarization of rat isolated superior cervical ganglia mediated by beta 2-adrenoceptors. Br. J. Pharmacol. 79: 429-39 [PMID:6140042]

52. Bruno JF, Whittaker J, Song JF and Berelowitz M. (1991) Molecular cloning and sequencing of a cDNA encoding a human alpha $1 \mathrm{~A}$ adrenergic receptor. Biochem. Biophys. Res. Commun. 179: 1485-90 [PMID:1656955]

53. Burcelin R, Uldry M, Foretz M, Perrin C, Dacosta A, Nenniger-Tosato M, Seydoux J, Cotecchia S and Thorens B. (2004) Impaired glucose homeostasis in mice lacking the alpha1b-adrenergic receptor subtype. J. Biol. Chem. 279: 1108-15 [PMID:14581480]

54. Bylund DB. (1992) Subtypes of alpha 1- and alpha 2-adrenergic receptors.FASEB J. 6: 832-9 [PMID:1346768]

55. Bylund DB. (1988) Subtypes of alpha 2-adrenoceptors: pharmacological and molecular biological evidence converge. Trends Pharmacol. Sci. 9: 356-61 [PMID:2855960]

56. Bylund DB. (2005) Alpha-2 adrenoceptor subtypes: are more better?Br. J. Pharmacol. 144: 159-60 [PMID:15655520]

57. Bylund DB, Blaxall HS, Iversen LJ, Caron MG, Lefkowitz RJ and Lomasney JW. (1992) Pharmacological characteristics of alpha 2-adrenergic receptors: comparison of pharmacologically defined subtypes with subtypes identified by molecular cloning. Mol Pharmacol. 42: 1-5 [PMID:1353247]

58. Bylund DB, Eikenberg DC, Hieble JP, Langer SZ, Lefkowitz RJ, Minneman KP, Molinoff PB, Ruffolo Jr RR and Trendelenburg U. (1994) International Union of Pharmacology nomenclature of adrenoceptors. Pharmacol. Rev. 46: 121-36 [PMID:7938162]

59. Bylund DB and Ray-Prenger C. (1989) Alpha-2A and alpha-2B adrenergic receptor subtypes: attenuation of cyclic AMP production in cell lines containing only one receptor subtype. J. Pharmacol. Exp. Ther. 251: 640-4 [PMID:2553931] 
60. Bylund DB, Ray-Prenger C and Murphy TJ. (1988) Alpha-2A and alpha-2B adrenergic receptor subtypes: antagonist binding in tissues and cell lines containing only one subtype. J. Pharmacol. Exp. Ther. 245: 6007 [PMID:2835476]

61. Callaerts-Vegh Z, Evans KL, Dudekula N, Cuba D, Knoll BJ, Callaerts PF, Giles H, Shardonofsky FR and Bond RA. (2004) Effects of acute and chronic administration of beta-adrenoceptor ligands on airway function in a murine model of asthma. Proc. Natl. Acad. Sci. U.S.A. 101: 4948-53 [PMID:15069206]

62. Candelore MR, Deng L, Tota L, Guan XM, Amend A, Liu Y, Newbold R, Cascieri MA and Weber AE. (1999) Potent and selective human beta(3)-adrenergic receptor antagonists. J. Pharmacol. Exp. Ther. 290: 649-55 [PMID:10411574]

63. Carroll WA, Sippy KB, Esbenshade TA, Buckner SA, Hancock AA and Meyer MD. (2001) Two novel and potent 3-[(o-methoxyphenyl)piperazinylethyl]-5-phenylthien. Bioorg. Med. Chem. Lett. 11: 1119-21 [PMID:11354357]

64. Casas-González P and García-Sáinz JA. (2006) Role of epidermal growth factor receptor transactivation in alpha1B-adrenoceptor phosphorylation. Eur. J. Pharmacol. 542: 31-6 [PMID:16828079]

65. Casas-González P, Ruiz-Martínez A and García-Sáinz JA. (2003) Lysophosphatidic acid induces alpha1B-adrenergic receptor phosphorylation through $\mathrm{G}$ beta gamma, phosphoinositide 3-kinase, protein kinase $C$ and epidermal growth factor receptor transactivation. Biochim. Biophys. Acta 1633: 75-83 [PMID:12880866]

66. Castillo-Badillo JA, Molina-Muñoz T, Romero-Ávila MT, Vázquez-Macías A, Rivera R, Chun J and GarcíaSáinz JA. (2012) Sphingosine 1-phosphate-mediated $\alpha 1 B$-adrenoceptor desensitization and phosphorylation. Direct and paracrine/autocrine actions. Biochim. Biophys. Acta 1823: 245-54 [PMID:22019450]

67. Castrejón-Sosa M, Villalobos-Molina R, Guinzberg R and Piña E. (2002) Adrenaline (via alpha(1B)adrenoceptors) and ethanol stimulate $\mathrm{OH}^{*}$ radical production in isolated rat hepatocytes. Life Sci. 71: 2469-74 [PMID:12270752]

68. Chalothorn D, McCune DF, Edelmann SE, Tobita K, Keller BB, Lasley RD, Perez DM, Tanoue A, Tsujimoto G and Post GR et al.. (2003) Differential cardiovascular regulatory activities of the alpha 1B-and alpha 1D-adrenoceptor subtypes. J. Pharmacol. Exp. Ther. 305: 1045-53 [PMID:12649302]

69. Chang DJ, Chang TK, Yamanishi SS, Salazar FH, Kosaka AH, Khare R, Bhakta S, Jasper JR, Shieh IS and Lesnick JD et al.. (1998) Molecular cloning, genomic characterization and expression of novel human alpha1A-adrenoceptor isoforms. FEBS Lett. 422: 279-83 [PMID:9490024]

70. Chen L, Hodges RR, Funaki C, Zoukhri D, Gaivin RJ, Perez DM and Dartt DA. (2006) Effects of alpha1Dadrenergic receptors on shedding of biologically active EGF in freshly isolated lacrimal gland epithelial cells. Am. J. Physiol., Cell Physiol. 291: C946-56 [PMID:16760267]

71. Chen Q, Takahashi S, Zhong S, Hosoda C, Zheng HY, Ogushi T, Fujimura T, Ohta N, Tanoue A and Tsujimoto $\mathrm{G}$ et al.. (2005) Function of the lower urinary tract in mice lacking alpha1d-adrenoceptor J. Urol. 174: 370-4 [PMID:15947692]

72. Chen WM, Chang AC, Shie BJ, Chang YH and Chang NC. (1992) Molecular cloning and characterization of a mouse alpha 2C2 adrenoceptor subtype gene. Biochim. Biophys. Acta 1171: 219-23 [PMID:1336396]

73. Chen Z, Hague C, Hall RA and Minneman KP. (2006) Syntrophins regulate alpha1D-adrenergic receptors through a PDZ domain-mediated interaction. J. Biol. Chem. 281: 12414-20 [PMID:16533813]

74. Chen Z, Rogge G, Hague C, Alewood D, Colless B, Lewis RJ and Minneman KP. (2004) Subtype-selective noncompetitive or competitive inhibition of human alpha1-adrenergic receptors by rho-TIA. J. Biol. Chem.

279: 35326-33 [PMID:15194691]

75. Cherezov V, Rosenbaum DM, Hanson MA, Rasmussen SG, Thian FS, Kobilka TS, Choi HJ, Kuhn P, Weis WI and Kobilka BK et al.. (2007) High-resolution crystal structure of an engineered human beta2adrenergic G protein-coupled receptor. Science 318: 1258-65 [PMID:17962520]

76. Chernogubova E, Cannon B and Bengtsson T. (2004) Norepinephrine increases glucose transport in brown adipocytes via beta3-adrenoceptors through a CAMP, PKA, and PI3-kinase-dependent pathway stimulating conventional and novel PKCs. Endocrinology 145: 269-280 [PMID:14551227] 
77. Chernogubova E, Hutchinson DS, Nedergaard J and Bengtsson T. (2005) Alpha1- and beta1adrenoceptor signaling fully compensates for beta3-adrenoceptor deficiency in brown adipocyte norepinephrine-stimulated glucose uptake. Endocrinology 146: 2271-84 [PMID:15665039]

78. Chiba $S$ and Tsukada M. (2002) Existence of functional alpha1A- and alpha1D- but no alpha1Badrenoceptor subtypes in rat common carotid arteries. Jpn. J. Pharmacol. 88: 146-50 [PMID:11928714]

79. Christiansen C, Poulsen P and Beck-Nielsen H. (1999) The Trp64Arg mutation of the adrenergic beta-3 receptor gene impairs insulin secretion: a twin study. Diabet. Med. 16: 835-40 [PMID:10547210]

80. Chruscinski AJ, Rohrer DK, Schauble E, Desai KH, Bernstein D and Kobilka BK. (1999) Targeted disruption of the beta2 adrenergic receptor gene. J. Biol. Chem. 274: 16694-700 [PMID:10358008]

81. Chung FZ, Lentes KU, Gocayne J, Fitzgerald M, Robinson D, Kerlavage AR, Fraser CM and Venter JC. (1987) Cloning and sequence analysis of the human brain beta-adrenergic receptor. Evolutionary relationship to rodent and avian beta-receptors and porcine muscarinic receptors. FEBS Lett. 211: 200-6 [PMID:3026848]

82. Clement K, Vaisse C, Manning BS, Basdevant A, Guy-Grand B, Ruiz J, Silver KD, Shuldiner AR, Froguel $P$ and Strosberg AD. (1995) Genetic variation in the beta 3-adrenergic receptor and an increased capacity to gain weight in patients with morbid obesity. N Engl J Med. 333: 352-354 [PMID:7609752]

83. Cockcroft JR, Gazis AG, Cross DJ, Wheatley A, Dewar J, Hall IP and Noon JP. (2000) Beta(2)adrenoceptor polymorphism determines vascular reactivity in humans. Hypertension 36: 371-5 [PMID:10988267]

84. Cohn HI, Harris DM, Pesant S, Pfeiffer M, Zhou RH, Koch WJ, Dorn GW and Eckhart AD. (2008) Inhibition of vascular smooth muscle $G$ protein-coupled receptor kinase 2 enhances alpha1D-adrenergic receptor constriction. Am. J. Physiol. Heart Circ. Physiol. 295: H1695-704 [PMID:18723764]

85. Conley RK, Williams TJ, Ford AP and Ramage AG. (2001) The role of alpha(1)-adrenoceptors and 5$\mathrm{HT}(1 \mathrm{~A})$ receptors in the control of the micturition reflex in male anaesthetized rats. Br. J. Pharmacol. 133: 61-72 [PMID:11325795]

86. Cotecchia S, Björklöf K, Rossier O, Stanasila L, Greasley P and Fanelli F. (2002) The alpha1b-adrenergic receptor subtype: molecular properties and physiological implications. J. Recept. Signal Transduct. Res.

22: 1-16 [PMID:12503605]

87. Cotecchia S, Schwinn DA, Randall RR, Lefkowitz RJ, Caron MG and Kobilka BK. (1988) Molecular cloning and expression of the cDNA for the hamster alpha 1-adrenergic receptor. Proc. Natl. Acad. Sci. U.S.A. 85: 7159-63 [PMID:2845398]

88. Cottingham C, Chen Y, Jiao K and Wang Q. (2011) The antidepressant desipramine is an arrestin-biased ligand at the $\alpha(2 \mathrm{~A})$-adrenergic receptor driving receptor down-regulation in vitro and in vivo. J. Biol. Chem. 286: 36063-75 [PMID:21859713]

89. Daniels DV, Gever JR, Jasper JR, Kava MS, Lesnick JD, Meloy TD, Stepan G, Williams TJ, Clarke DE and Chang DJ et al.. (1999) Human cloned alpha1A-adrenoceptor isoforms display alpha1L-adrenoceptor pharmacology in functional studies. Eur. J. Pharmacol. 370: 337-43 [PMID:10334511]

90. Dardonville $C$ and Rozas I. (2004) Imidazoline binding sites and their ligands: an overview of the different chemical structures. Med Res Rev24: 639-61 [PMID:15224384]

91. Dartt DA and Hodges RR. (2011) Interaction of alpha1D-adrenergic and P2X(7) receptors in the rat lacrimal gland and the effect on intracellular $[\mathrm{Ca} 2+]$ and protein secretion. Invest. Ophthalmol. Vis. Sci. 52: 5720-9 [PMID:21685341]

92. Day HE, Campeau S, Watson Jr SJ and Akil H. (1997) Distribution of alpha 1a-, alpha 1b- and alpha 1dadrenergic receptor mRNA in the rat brain and spinal cord. J. Chem. Neuroanat. 13: 115-39 [PMID:9285356]

93. Day HE, Kryskow EM, Watson SJ, Akil H and Campeau S. (2008) Regulation of hippocampal alpha1d adrenergic receptor mRNA by corticosterone in adrenalectomized rats. Brain Res. 1218: $132-40$ [PMID:18534559]

94. de Andrade CR, Fukada SY, Olivon VC, de Godoy MA, Haddad R, Eberlin MN, Cunha FQ, de Souza HP, Laurindo FR and de Oliveira AM. (2006) Alpha1D-adrenoceptor-induced relaxation on rat carotid artery is 
impaired during the endothelial dysfunction evoked in the early stages of hyperhomocysteinemia. Eur. $J$. Pharmacol. 543: 83-91 [PMID:16828078]

95. De Ponti F, Gibelli G, Croci T, Arcidiaco M, Crema F and Manara L. (1996) Functional evidence of atypical beta 3-adrenoceptors in the human colon using the beta 3-selective adrenoceptor antagonist, SR 59230A. Br. J. Pharmacol. 117: 1374-6 [PMID:8730727]

96. DeBoy JM and Jarboe BR. (1991) A response to "Can cytology proficiency testing programs discriminate between competent and incompetent practitioners?". QRB Qual Rev Bull 17: 206 [PMID:1923452]

97. Deighan C, Woollhead AM, Colston JF and McGrath JC. (2004) Hepatocytes from alpha1B-adrenoceptor knockout mice reveal compensatory adrenoceptor subtype substitution. Br. J. Pharmacol. 142: 1031-7 [PMID:15210583]

98. Dessy C, Moniotte S, Ghisdal P, Havaux X, Noirhomme P and Balligand JL. (2004) Endothelial beta3adrenoceptors mediate vasorelaxation of human coronary microarteries through nitric oxide and endothelium-dependent hyperpolarization. Circulation 110: 948-54 [PMID:15302798]

99. Deupree JD, Hinton KA, Cerutis DR and Bylund DB. (1996) Buffers differentially alter the binding of $[3 \mathrm{H}]$ rauwolscine and $[3 \mathrm{H}] \mathrm{RX} 821002$ to the alpha-2 adrenergic receptor subtypes. J. Pharmacol. Exp. Ther. 278: 1215-27 [PMID:8819505]

100. Devedjian JC, Esclapez F, Denis-Pouxviel C and Paris H. (1994) Further characterization of human alpha 2-adrenoceptor subtypes: [3H]RX821002 binding and definition of additional selective drugs. Eur. J. Pharmacol. 252: 43-9 [PMID:7908642]

101. Diamanti E, Del Bello F, Carbonara G, Carrieri A, Fracchiolla G, Giannella M, Mammoli V, Piergentili A, Pohjanoksa K and Quaglia W et al.. (2012) Might the observed $\alpha(2 A)$-adrenoreceptor agonism or antagonism of allyphenyline analogues be ascribed to different molecular conformations? Bioorg. Med. Chem. 20: 2082-90 [PMID:22341244]

102. Dixon RA, Kobilka BK, Strader DJ, Benovic JL, Dohlman HG, Frielle T, Bolanowski MA, Bennett CD, Rands $E$ and Diehl RE et al.. (1986) Cloning of the gene and cDNA for mammalian beta-adrenergic receptor and homology with rhodopsin. Nature 321: 75-9 [PMID:3010132]

103. Docherty JR. (2011) Vasopressor nerve responses in the pithed rat, previously identified as $\alpha 2-$ adrenoceptor mediated, may be $\alpha 1 \mathrm{D}$-adrenoceptor mediated. Eur. J. Pharmacol. 658: 182-6 [PMID:21376031]

104. Docherty JR. (2012) Yohimbine antagonises $\alpha 1 \mathrm{~A}$ - and $\alpha 1 \mathrm{D}$-adrenoceptor mediated components in addition to the $\alpha 2 \mathrm{~A}$-adrenoceptor component to pressor responses in the pithed rat. Eur. J. Pharmacol. 679: 90-4 [PMID:22290390]

105. Docherty JR. (1998) Subtypes of functional alpha1- and alpha2-adrenoceptors.Eur. J. Pharmacol. 361: 115 [PMID:9851536]

106. Dolan JA, Muenkel HA, Burns MG, Pellegrino SM, Fraser CM, Pietri F, Strosberg AD, Largis EE, Dutia MD and Bloom JD et al.. (1994) Beta-3 adrenoceptor selectivity of the dioxolane dicarboxylate phenethanolamines. J. Pharmacol. Exp. Ther. 269: 1000-6 [PMID:7912272]

107. Doze VA, Papay RS, Goldenstein BL, Gupta MK, Collette KM, Nelson BW, Lyons MJ, Davis BA, Luger EJ and Wood SG et al.. (2011) Long-term $\alpha 1 A$-adrenergic receptor stimulation improves synaptic plasticity, cognitive function, mood, and longevity. Mol. Pharmacol. 80: 747-58 [PMID:21791575]

108. Drake MT, Violin JD, Whalen EJ, Wisler JW, Shenoy SK and Lefkowitz RJ. (2008) beta-arrestin-biased agonism at the beta2-adrenergic receptor. J. Biol. Chem. 283: 5669-76 [PMID:18086673]

109. Drouin C, Darracq L, Trovero F, Blanc G, Glowinski J, Cotecchia S and Tassin JP. (2002) Alpha1badrenergic receptors control locomotor and rewarding effects of psychostimulants and opiates. $J$. Neurosci. 22: 2873-84 [PMID:11923452]

110. Du XJ, Fang L, Gao XM, Kiriazis H, Feng X, Hotchkin E, Finch AM, Chaulet H and Graham RM. (2004) Genetic enhancement of ventricular contractility protects against pressure-overload-induced cardiac dysfunction. J. Mol. Cell. Cardiol. 37: 979-87 [PMID:15522275]

111. Du XJ, Gao XM, Kiriazis H, Moore XL, Ming Z, Su Y, Finch AM, Hannan RA, Dart AM and Graham RM. (2006) Transgenic alpha1A-adrenergic activation limits post-infarct ventricular remodeling and dysfunction 
and improves survival. Cardiovasc. Res. 71: 735-43 [PMID:16859660]

112. Ducza E, Kormányos Z, Resch BE and Falkay G. (2005) Correlation between the alterations in the mRNA expressions of the alpha1-adrenoceptor and estrogen receptor subtypes in the pregnant human uterus and cervix. Eur. J. Pharmacol. 528: 183-7 [PMID:16325176]

113. Eason MG, Kurose H, Holt BD, Raymond JR and Liggett SB. (1992) Simultaneous coupling of alpha 2adrenergic receptors to two G-proteins with opposing effects. Subtype-selective coupling of alpha $2 \mathrm{C} 10$, alpha 2C4, and alpha 2C2 adrenergic receptors to Gi and Gs. J. Biol. Chem. 267: 15795-801 [PMID:1322406]

114. Eason MG and Liggett SB. (1995) Identification of a Gs coupling domain in the amino terminus of the third intracellular loop of the alpha 2A-adrenergic receptor. Evidence for distinct structural determinants that confer Gs versus Gi coupling. J. Biol. Chem. 270: 24753-60 [PMID:7559592]

115. Eason MG and Liggett SB. (1993) Human alpha 2-adrenergic receptor subtype distribution: widespread and subtype-selective expression of alpha $2 \mathrm{C} 10$, alpha $2 \mathrm{C} 4$, and alpha $2 \mathrm{C} 2 \mathrm{mRNA}$ in multiple tissues. Mol. Pharmacol. 44: 70-5 [PMID:7688069]

116. Elenkov IJ, Wilder RL, Chrousos GP and Vizi ES. (2000) The sympathetic nerve--an integrative interface between two supersystems: the brain and the immune system. Pharmacol. Rev. 52: 595-638 [PMID:11121511]

117. Emorine LJ, Marullo S, Briend-Sutren MM, Patey G, Tate K, Delavier-Klutchko C and Strosberg AD. (1989) Molecular characterization of the human beta 3-adrenergic receptor. Science 245: 1118-21 [PMID:2570461]

118. Errasti AE, Werneck de Avellar MC, Daray FM, Tramontano J, Luciani LI, Lina Bard MJ, Maróstica E and Rothlin RP. (2003) Human umbilical vein vasoconstriction induced by epinephrine acting on alpha1Badrenoceptor subtype. Am. J. Obstet. Gynecol. 189: 1472-80 [PMID:14634588]

119. Evans BA, Broxton N, Merlin J, Sato M, Hutchinson DS, Christopoulos A and Summers RJ. (2011) Quantification of functional selectivity at the human $\alpha(1 \mathrm{~A})$-adrenoceptor. Mol. Pharmacol. 79: 298-307 [PMID:20978120]

120. Evans BA, Papaioannou M, Hamilton S and Summers RJ. (1999) Alternative splicing generates two isoforms of the beta-3 adrenoceptor which are differentially expressed in mouse tissues. Br. J. Pharmacol. 127: 1525-1531 [PMID:10455305]

121. Evans BA, Sato M, Sarwar M, Hutchinson DS and Summers RJ. (2010) Ligand-directed signalling at betaadrenoceptors. Br. J. Pharmacol. 159: 1022-38 [PMID:20132209]

122. Fargin A, Raymond SR, Lohse MJ, Kobilka BK, Caron MG and Lefkowitz RJ. (1988) The genomic clone G21 which resembles a $\beta$-adrenergic receptor sequence encodes the 5- $\mathrm{HT}_{1 \mathrm{~A}}$ receptor. Nature 335: 358-360 [PMID:3138543]

123. Fernández J, Alonso JM, Andrés JI, Cid JM, Díaz A, Iturrino L, Gil P, Megens A, Sipido VK and Trabanco AA. (2005) Discovery of new tetracyclic tetrahydrofuran derivatives as potential broad-spectrum psychotropic agents. J. Med. Chem. 48: 1709-12 [PMID:15771415]

124. Festa A, Krugluger W, Shnawa N, Hopmeier P, Haffner SM and Schernthaner G. (1999) Trp64Arg polymorphism of the beta3-adrenergic receptor gene in pregnancy: association with mild gestational diabetes mellitus. J. Clin. Endocrinol. Metab. 84: 1695-9 [PMID:10323402]

125. Filippi S, Parenti A, Donnini S, Granger HJ, Fazzini A and Ledda F. (2001) alpha(1D)-adrenoceptors cause endothelium-dependent vasodilatation in the rat mesenteric vascular bed. J. Pharmacol. Exp. Ther. 296: 869-75 [PMID:11181918]

126. Flacco N, Segura V, Perez-Aso M, Estrada S, Seller JF, Jiménez-Altayó F, Noguera MA, D'Ocon P, Vila E and Ivorra MD. (2013) Different $\beta$-adrenoceptor subtypes coupling to cAMP or NO/cGMP pathways: implications in the relaxant response of rat conductance and resistance vessels. Br. J. Pharmacol. 169: 413-25 [PMID:23373597]

127. Fletcher DS, Candelore MR, Grujic D, Lowell BB, Luell S, Susulic VS and Macintyre DE. (1998) Beta-3 adrenergic receptor agonists cause an increase in gastrointestinal transit time in wild-type mice, but not in mice lacking the beta-3 adrenergic receptor. J. Pharmacol. Exp. Ther. 287: 720-4 [PMID:9808702] 
128. Flordellis CS, Handy DE, Bresnahan MR, Zannis VI and Gavras H. (1991) Cloning and expression of a rat brain alpha 2B-adrenergic receptor. Proc. Natl. Acad. Sci. U.S.A. 88: 1019-23 [PMID:1704126]

129. Ford AP, Arredondo NF, Blue Jr DR, Bonhaus DW, Jasper J, Kava MS, Lesnick J, Pfister JR, Shieh IA and Vimont RL et al.. (1996) RS-17053 (N-[2-(2-cyclopropylmethoxyphenoxy)ethyl]-5-chloro-alpha, alphadimethyl-1H-indole-3-ethanamine hydrochloride), a selective alpha $1 \mathrm{~A}$-adrenoceptor antagonist, displays low affinity for functional alpha 1-adrenoceptors in human prostate: implications for adrenoceptor classification. Mol. Pharmacol. 49: 209-15 [PMID:8632751]

130. Ford AP, Daniels DV, Chang DJ, Gever JR, Jasper JR, Lesnick JD and Clarke DE. (1997) Pharmacological pleiotropism of the human recombinant alpha1A-adrenoceptor: implications for alpha1adrenoceptor classification. Br. J. Pharmacol. 121: 1127-35 [PMID:9249248]

131. Ford AP, Williams TJ, Blue DR and Clarke DE. (1994) Alpha 1-adrenoceptor classification: sharpening Occam's razor. Trends Pharmacol. Sci. 15: 167-70 [PMID:7916507]

132. Freitas SR, Pereira AC, Floriano MS, Mill JG and Krieger JE. (2008) Association of alpha1a-adrenergic receptor polymorphism and blood pressure phenotypes in the Brazilian population. BMC CardiovasC Disord 8: 40 [PMID:19105822]

133. Frielle T, Collins S, Daniel KW, Caron MG, Lefkowitz RJ and Kobilka BK. (1987) Cloning of the cDNA for the human $\beta 1$-adrenergic receptor. Proc. Natl. Acad. Sci. U.S.A. 84: 7920-7924 [PMID:2825170]

134. Frielle T, Daniel KW, Caron MG and Lefkowitz RJ. (1988) Structural basis of beta-adrenergic receptor subtype specificity studied with chimeric beta $1 /$ beta 2 -adrenergic receptors. Proc. Natl. Acad. Sci. U.S.A. 85: 9494-8 [PMID:2849109]

135. Gable BD, Shiga T, Murray PA and Damron DS. (2005) Propofol increases contractility during alpha1aadrenoreceptor activation in adult rat cardiomyocytes. Anesthesiology 103: 335-43 [PMID:16052116]

136. Galandrin S and Bouvier M. (2006) Distinct signaling profiles of beta1 and beta2 adrenergic receptor ligands toward adenylyl cyclase and mitogen-activated protein kinase reveals the pluridimensionality of efficacy. Mol. Pharmacol. 70: 1575-84 [PMID:16901982]

137. Galandrin S, Oligny-Longpré G, Bonin H, Ogawa K, Galés C and Bouvier M. (2008) Conformational rearrangements and signaling cascades involved in ligand-biased mitogen-activated protein kinase signaling through the beta1-adrenergic receptor. Mol. Pharmacol. 74: 162-72 [PMID:18403719]

138. Galitzky J, Langin D, Verwaerde P, Montastruc JL, Lafontan M and Berlan M. (1997) Lipolytic effects of conventional beta 3-adrenoceptor agonists and of CGP 12,177 in rat and human fat cells: preliminary pharmacological evidence for a putative beta 4-adrenoceptor. Br. J. Pharmacol. 122: 1244-50 [PMID:9401793]

139. García-Cazarín ML, Smith JL, Clair DK and Piascik MT. (2008) The alpha1D-adrenergic receptor induces vascular smooth muscle apoptosis via a p53-dependent mechanism. Mol. Pharmacol. 74: 1000-7 [PMID:18628404]

140. García-Cazarín ML, Smith JL, Olszewski KA, McCune DF, Simmerman LA, Hadley RW, Kraner SD and Piascik MT. (2008) The alpha1D-adrenergic receptor is expressed intracellularly and coupled to increases in intracellular calcium and reactive oxygen species in human aortic smooth muscle cells. J Mol Signa/3: 6 [PMID:18304336]

141. García-Sáinz JA, Rodríguez-Pérez CE and Romero-Avila MT. (2004) Human alpha1D-adrenoceptor phosphorylation and desensitization. Biochem. Pharmacol. 67: 1853-8 [PMID:15130762]

142. García-Sáinz JA, Romero-Avila MT, Molina-Muñoz T and Medina Ldel C. (2004) Insulin induces alpha1Badrenergic receptor phosphorylation and desensitization. Life Sci. 75: 1937-47 [PMID:15306161]

143. García-Sáinz JA, Vázquez-Cuevas FG and Romero-Avila MT. (2001) Phosphorylation and desensitization of alpha1d-adrenergic receptors. Biochem. J. 353: 603-10 [PMID:11171057]

144. Garovic VD, Joyner MJ, Dietz NM, Boerwinkle E and Turner ST. (2003) Beta(2)-adrenergic receptor polymorphism and nitric oxide-dependent forearm blood flow responses to isoproterenol in humans. $J$. Physiol. (Lond.) 546: 583-9 [PMID:12527744]

145. Gauthier C, Tavernier G, Charpentier F, Langin D and Le Marec H. (1996) Functional beta3-adrenoceptor in the human heart. J. Clin. Invest. 98: 556-62 [PMID:8755668] 
146. Gavin KT, Colgan MP, Moore D, Shanik G and Docherty JR. (1997) Alpha 2C-adrenoceptors mediate contractile responses to noradrenaline in the human saphenous vein. Naunyn Schmiedebergs Arch. Pharmacol. 355: 406-11 [PMID:9089673]

147. Germack R, Starzec AB, Vassy R and Perret GY. (1997) Beta-adrenoceptor subtype expression and function in rat white adipocytes. Br. J. Pharmacol. 120: 201-10 [PMID:9117110]

148. Giardinà D, Crucianelli $M$, Romanelli R, Leonardi A, Poggesi E and Melchiorre C. (1996) Synthesis and biological profile of the enantiomers of [4-(4-amino-6,7-dimethoxyquinazolin-2-yl)-cis-octahydroquinoxalin1-yl]furan-2-ylmethanone (cyclazosin), a potent competitive alpha 1B- adrenoceptor antagonist. J. Med. Chem. 39: 4602-7 [PMID:8917649]

149. Giessler C, Wangemann T, Silber RE, Dhein S and Brodde OE. (2002) Noradrenaline-induced contraction of human saphenous vein and human internal mammary artery: involvement of different alphaadrenoceptor subtypes. Naunyn Schmiedebergs Arch. Pharmacol. 366: 104-9 [PMID:12122495]

150. Gocayne J Robinson DA, FitzGerald MG, Chung FZ, Kerlavage AR, Lentes KU, Lai J Wang CD, Fraser CM and Venter JC. (1987) Primary structure of rat cardiac beta-adrenergic and muscarinic cholinergic receptors obtained by automated DNA sequence analysis: further evidence for a multigene family. Proc Natl Acad Sci U S A 84: 8296-8300 [PMID:2825184]

151. Gonzalez-Cabrera PJ, Shi T, Yun J, McCune DF, Rorabaugh BR and Perez DM. (2004) Differential regulation of the cell cycle by alpha1-adrenergic receptor subtypes. Endocrinology 145: 5157-67 [PMID:15297446]

152. González-Arenas A, Aguilar-Maldonado B, Avendaño-Vázquez SE and García-Sáinz JA. (2006) Estrogens cross-talk to alpha1b-adrenergic receptors. Mol. Pharmacol. 70: 154-62 [PMID:16638969]

153. González-Hernández Mde L, Godínez-Hernández D, Bobadilla-Lugo RA and López-Sánchez P. (2010) Angiotensin-II type 1 receptor (AT1R) and alpha-1D adrenoceptor form a heterodimer during pregnancyinduced hypertension. Auton Autacoid Pharmaco/30: 167-72 [PMID:20102360]

154. Granneman JG, Lahners KN and Chaudhry A. (1991) Molecular cloning and expression of the rat beta 3adrenergic receptor. Mol Pharmacol. 40: 895-899 [PMID:1684635]

155. Gray K, Short J and Ventura S. (2008) The alpha1A-adrenoceptor gene is required for the alpha1Ladrenoceptor-mediated response in isolated preparations of the mouse prostate. Br. J. Pharmacol. 155: 103-9 [PMID:18552869]

156. Gu D, Ge D, Snieder H, He J, Chen S, Huang J, Li B, Chen R and Qiang B. (2006) Association of alpha1A adrenergic receptor gene variants on chromosome 8p21 with human stage 2 hypertension. J. Hypertens.

24: 1049-56 [PMID:16685204]

157. Gupta MK, Papay RS, Jurgens CW, Gaivin RJ, Shi T, Doze VA and Perez DM. (2009) alpha1-Adrenergic receptors regulate neurogenesis and gliogenesis. Mol. Pharmacol. 76: 314-26 [PMID:19487244]

158. Haack KK, Tougas MR, Jones KT, El-Dahr SS, Radhakrishna H and McCarty NA. (2010) A novel bioassay for detecting GPCR heterodimerization: transactivation of beta 2 adrenergic receptor by bradykinin receptor. J Biomol Screen 15: 251-60 [PMID:20150590]

159. Hague C, Bernstein LS, Ramineni S, Chen Z, Minneman KP and Hepler JR. (2005) Selective inhibition of alpha1A-adrenergic receptor signaling by RGS2 association with the receptor third intracellular loop. $J$. Biol. Chem. 280: 27289-95 [PMID:15917235]

160. Hague C, Chen Z, Pupo AS, Schulte NA, Toews ML and Minneman KP. (2004) The N terminus of the human alpha1D-adrenergic receptor prevents cell surface expression. J. Pharmacol. Exp. Ther. 309: 38897 [PMID:14718583]

161. Hague C, Chen Z, Uberti M and Minneman KP. (2003) Alpha(1)-adrenergic receptor subtypes: nonidentical triplets with different dancing partners? Life Sci. 74: 411-8 [PMID:14609720]

162. Hague C, Lee SE, Chen Z, Prinster SC, Hall RA and Minneman KP. (2006) Heterodimers of alpha1B- and alpha1D-adrenergic receptors form a single functional entity. Mol. Pharmacol. 69: 45-55 [PMID:16195468]

163. Hague C, Uberti MA, Chen Z, Bush CF, Jones SV, Ressler KJ, Hall RA and Minneman KP. (2004) Olfactory receptor surface expression is driven by association with the beta2-adrenergic receptor. Proc. Natl. Acad. Sci. U.S.A. 101: 13672-6 [PMID:15347813] 
164. Hague C, Uberti MA, Chen Z, Hall RA and Minneman KP. (2004) Cell surface expression of alpha1Dadrenergic receptors is controlled by heterodimerization with alpha1B-adrenergic receptors. J. Biol. Chem. 279: 15541-9 [PMID:14736874]

165. Hampel C, Dolber PC, Smith MP, Savic SL, Th roff JW, Thor KB and Schwinn DA. (2002) Modulation of bladder alpha1-adrenergic receptor subtype expression by bladder outlet obstruction. J. Urol. 167: 1513-21 [PMID:11832780]

166. Han C, Abel PW and Minneman KP. (1987) Alpha 1-adrenoceptor subtypes linked to different mechanisms for increasing intracellular Ca2+ in smooth muscle. Nature 329: 333-5 [PMID:2442626]

167. Han JL, Zhang YY, Lü ZZ, Mao JM, Chen MZ and Han QD. (2003) Functional alpha1-adrenergic receptor subtypes in human right gastroepiploic artery. Acta Pharmacol. Sin. 24: 327-31 [PMID:12676072]

168. Hancock AA, Buckner SA, Brune ME, Katwala S, Milicic I, Ireland LM, Morse PA, Knepper SM, Meyer MD and Chapple CR et al.. (1998) Pharmacological characterization of A-131701, a novel R 1 -adrenoceptor antagonist selective for R $1 \mathrm{~A}$ - and R 1D - compared to R 1B -adrenoceptors. Drug Development Research 44: 140-162

169. Hancock AA, DeLean AL and Lefkowitz RJ. (1979) Quantitative resolution of beta-adrenergic receptor subtypes by selective ligand binding: application of a computerized model fitting technique. Mol. Pharmacol. 16: 1-9 [PMID:39239]

170. Handy DE, Flordellis CS, Bogdanova NN, Bresnahan MR and Gavras H. (1993) Diverse tissue expression of rat alpha 2-adrenergic receptor genes. Hypertension 21: 861-5 [PMID:7684725]

171. Hanson MA, Cherezov V, Griffith MT, Roth CB, Jaakola VP, Chien EY, Velasquez J, Kuhn P and Stevens RC. (2008) A specific cholesterol binding site is established by the 2.8 A structure of the human beta2adrenergic receptor. Structure 16: 897-905 [PMID:18547522]

172. Harasawa I, Honda K, Tanoue A, Shinoura H, Ishida Y, Okamura H, Murao N, Tsujimoto G, Higa K and Kamiya $\mathrm{HO}$ et al.. (2003) Responses to noxious stimuli in mice lacking alpha(1d)-adrenergic receptors. Neuroreport 14: 1857-60 [PMID:14534435]

173. Hebert TE, Moffett S, Morello JP, Loisel TP, Bichet DG, Barret C and Bouvier M. (1996) A peptide derived from a beta2-adrenergic receptor transmembrane domain inhibits both receptor dimerization and activation. J. Biol. Chem. 271: 16384-92 [PMID:8663163]

174. Hein L, Altman JD and Kobilka BK. (1999) Two functionally distinct alpha2-adrenergic receptors regulate sympathetic neurotransmission. Nature 402: 181-4 [PMID:10647009]

175. Hein L, Limbird LE, Eglen RM and Kobilka BK. (1999) Gene substitution/knockout to delineate the role of alpha 2-adrenoceptor subtypes in mediating central effects of catecholamines and imidazolines. Ann. N. Y. Acad. Sci. 881: 265-71 [PMID:10415924]

176. Hein $P$ and Michel MC. (2007) Signal transduction and regulation: are all alpha1-adrenergic receptor subtypes created equal? Biochem. Pharmacol. 73: 1097-106 [PMID:17141737]

177. Heubach JF, Trebess I, Wettwer E, Himmel HM, Michel MC, Kaumann AJ, Koch WJ, Harding SE and Ravens U. (1999) L-type calcium current and contractility in ventricular myocytes from mice overexpressing the cardiac beta 2-adrenoceptor. Cardiovasc. Res. 42: 173-82 [PMID:10435008]

178. Hieble JP. (2000) Adrenoceptor subclassification: an approach to improved cardiovascular therapeutics. Pharm Acta Helv 74: 163-71 [PMID:10812954]

179. Hieble JP, Bondinell WE and Ruffolo Jr RR. (1995) Alpha- and beta-adrenoceptors: from the gene to the clinic. 1. Molecular biology and adrenoceptor subclassification. J. Med. Chem. 38: 3415-44 [PMID:7658428]

180. Hieble JP, Bylund DB, Clarke DE, Eikenburg DC, Langer SZ, Lefkowitz RJ, Minneman KP and Ruffolo Jr RR. (1995) International Union of Pharmacology. X. Recommendation for nomenclature of alpha 1adrenoceptors: consensus update. Pharmacol. Rev. 47: 267-70 [PMID:7568329]

181. Hieble JP and Ruffolo Jr RR. (1997) Recent advances in the identification of alpha1- and alpha2adrenoceptor subtypes: therapeutic implications. Expert Opin Investig Drugs 6: 367-87 [PMID:15989605]

182. Hieble JP and Ruffolo Jr RR. (1996) Subclassification and nomenclature of alpha 1- and alpha 2adrenoceptors. Prog Drug Res 47: 81-130 [PMID:8961765] 
183. Hillman KL, Doze VA and Porter JE. (2005) Functional characterization of the beta-adrenergic receptor subtypes expressed by CA1 pyramidal cells in the rat hippocampus. J. Pharmacol. Exp. Ther. 314: 561-7 [PMID:15908513]

184. Hirasawa A, Shibata K, Horie K, Takei Y, Obika K, Tanaka T, Muramoto N, Takagaki K, Yano J and Tsujimoto G. (1995) Cloning, functional expression and tissue distribution of human alpha 1c-adrenoceptor splice variants. FEBS Lett. 363: 256-60 [PMID:7737411]

185. Hodges RR, Shatos MA, Tarko RS, Vrouvlianis J, Gu J and Dartt DA. (2005) Nitric oxide and cGMP mediate alpha1D-adrenergic receptor-Stimulated protein secretion and p42/p44 MAPK activation in rat lacrimal gland. Invest. Ophthalmol. Vis. Sci. 46: 2781-9 [PMID:16043851]

186. Hoffmann C, Leitz MR, Oberdorf-Maass S, Lohse MJ and Klotz KN. (2004) Comparative pharmacology of human beta-adrenergic receptor subtypes--characterization of stably transfected receptors in $\mathrm{CHO}$ cells. Naunyn Schmiedebergs Arch. Pharmacol. 369: 151-9 [PMID:14730417]

187. Hoit BD, Suresh DP, Craft L, Walsh RA and Liggett SB. (2000) beta2-adrenergic receptor polymorphisms at amino acid 16 differentially influence agonist-stimulated blood pressure and peripheral blood flow in normal individuals. Am. Heart J. 139: 537-42 [PMID:10689270]

188. Horie K, Obika K, Foglar R and Tsujimoto G. (1995) Selectivity of the imidazoline alpha-adrenoceptor agonists (oxymetazoline and cirazoline) for human cloned alpha 1-adrenoceptor subtypes. Br. J. Pharmacol. 116: 1611-8 [PMID:8564227]

189. Hosoda C, Koshimizu TA, Tanoue A, Nasa Y, Oikawa R, Tomabechi T, Fukuda S, Shinoura H, Oshikawa $S$ and Takeo $S$ et al.. (2005) Two alpha1-adrenergic receptor subtypes regulating the vasopressor response have differential roles in blood pressure regulation. Mol. Pharmacol. 67: 912-22 [PMID:15598970]

190. Hrometz SL, Edelmann SE, McCune DF, Olges JR, Hadley RW, Perez DM and Piascik MT. (1999) Expression of multiple alpha1-adrenoceptors on vascular smooth muscle: correlation with the regulation of contraction. J. Pharmacol. Exp. Ther. 290: 452-63 [PMID:10381812]

191. Huang HH, Brennan TC, Muir MM and Mason RS. (2009) Functional alpha1- and beta2-adrenergic receptors in human osteoblasts. J. Cell. Physiol. 220: 267-75 [PMID:19334040]

192. Huang Y, Wright CD, Merkwan CL, Baye NL, Liang Q, Simpson PC and O'Connell TD. (2007) An alpha1Aadrenergic-extracellular signal-regulated kinase survival signaling pathway in cardiac myocytes.

Circulation 115: 763-72 [PMID:17283256]

193. Hudson BD, Hébert TE and Kelly ME. (2010) Physical and functional interaction between CB1 cannabinoid receptors and beta2-adrenoceptors. Br. J. Pharmacol. 160: 627-42 [PMID:20590567]

194. Hunter JC, Fontana DJ, Hedley LR, Jasper JR, Lewis R, Link RE, Secchi R, Sutton J and Eglen RM. (1997) Assessment of the role of alpha2-adrenoceptor subtypes in the antinociceptive, sedative and hypothermic action of dexmedetomidine in transgenic mice. Br. J. Pharmacol. 122: 1339-44 [PMID:9421280]

195. Huo S, Zhong X, Wu X and Li Y. (2012) Effects of norepinephrine and acetylcholine on the development of cultured Leydig cells in mice. J. Biomed. Biotechnol. 2012: 503093 [PMID:23093848]

196. Hutchinson DS, Bengtsson T, Evans BA and Summers RJ. (2002) Mouse beta 3a- and beta 3badrenoceptors expressed in Chinese hamster ovary cells display identical pharmacology but utilize distinct signalling pathways. Br. J. Pharmacol. 135: 1903-14 [PMID:11959793]

197. Hutchinson DS, Chernogubova E, Sato M, Summers RJ and Bengtsson T. (2006) Agonist effects of zinterol at the mouse and human beta(3)-adrenoceptor. Naunyn Schmiedebergs Arch. Pharmacol. 373: 158-68 [PMID:16601951]

198. Hwa J, Graham RM and Perez DM. (1996) Chimeras of alpha1-adrenergic receptor subtypes identify critical residues that modulate active state isomerization. J. Biol. Chem. 271: 7956-64 [PMID:8626475]

199. Hwa J, Graham RM and Perez DM. (1995) Identification of critical determinants of alpha 1-adrenergic receptor subtype selective agonist binding. J. Biol. Chem. 270: 23189-95 [PMID:7559466]

200. Hwa J and Perez DM. (1996) The unique nature of the serine interactions for alpha 1-adrenergic receptor agonist binding and activation. J. Biol. Chem. 271: 6322-7 [PMID:8626427] 
201. Ishibashi T, Horisawa T, Tokuda K, Ishiyama T, Ogasa M, Tagashira R, Matsumoto K, Nishikawa H, Ueda $Y$ and Toma $S$ et al.. (2010) Pharmacological profile of lurasidone, a novel antipsychotic agent with potent 5-hydroxytryptamine 7 (5-HT7) and 5-HT1A receptor activity. J. Pharmacol. Exp. Ther. 334: 171-81 [PMID:20404009]

202. Ishihama H, Momota Y, Yanase H, Wang X, de Groat WC and Kawatani M. (2006) Activation of alpha1D adrenergic receptors in the rat urothelium facilitates the micturition reflex. J. Urol. 175: 358-64 [PMID:16406942]

203. Isogaya M, Sugimoto $Y$, Tanimura R, Tanaka R, Kikkawa H, Nagao T and Kurose H. (1999) Binding pockets of the beta(1)- and beta(2)-adrenergic receptors for subtype-selective agonists. Mol. Pharmacol. 56: 875-85 [PMID:10531390]

204. Izeboud CA, Vermeulen RM, Zwart A, Voss HP, van Miert AS and Witkamp RF. (2000) Stereoselectivity at the beta2-adrenoceptor on macrophages is a major determinant of the anti-inflammatory effects of beta2agonists. Naunyn Schmiedebergs Arch. Pharmacol. 362: 184-9 [PMID:10961382]

205. January B, Seibold A, Whaley B, Hipkin RW, Lin D, Schonbrunn A, Barber R and Clark RB. (1997) beta2adrenergic receptor desensitization, internalization, and phosphorylation in response to full and partial agonists. J. Biol. Chem. 272: 23871-9 [PMID:9295336]

206. Jarajapu YP, Johnston F, Berry C, Renwick A, McGrath JC, MacDonald A and Hillier C. (2001) Functional characterization of alpha1-adrenoceptor subtypes in human subcutaneous resistance arteries. $J$. Pharmacol. Exp. Ther. 299: 729-34 [PMID:11602687]

207. Jarajapu YP, McGrath JC, Hillier C and MacDonald A. (2003) The alpha 1-adrenoceptor profile in human skeletal muscle resistance arteries in critical limb ischaemia. Cardiovasc. Res. 57: 554-62 [PMID:12566128]

208. Jasper JR, Lesnick JD, Chang LK, Yamanishi SS, Chang TK, Hsu SA, Daunt DA, Bonhaus DW and Eglen RM. (1998) Ligand efficacy and potency at recombinant alpha2 adrenergic receptors: agonist-mediated [35S]GTPgammaS binding. Biochem. Pharmacol. 55: 1035-43 [PMID:9605427]

209. Jasper JR, Link RE, Chruscinski AJ, Kobilka BK and Bernstein D. (1993) Primary structure of the mouse beta 1-adrenergic receptor gene. Biochim. Biophys. Acta 1178: 307-9 [PMID:8395893]

210. Jensen BC, Swigart PM, Laden ME, DeMarco T, Hoopes C and Simpson PC. (2009) The alpha-1D Is the predominant alpha-1-adrenergic receptor subtype in human epicardial coronary arteries. J. Am. Coll. Cardiol. 54: 1137-45 [PMID:19761933]

211. Jensen BC, Swigart PM, Montgomery MD and Simpson PC. (2010) Functional alpha-1B adrenergic receptors on human epicardial coronary artery endothelial cells. Naunyn Schmiedebergs Arch. Pharmacol. 382: 475-82 [PMID:20857090]

212. Jiang S, Mao G, Zhang S, Hong X, Tang G, Li Z, Liu X, Zhang Y, Wang B and Xu Xtt al.. (2005) Individual and joint association of alpha1A-adrenergic receptor Arg347Cys polymorphism and plasma irbesartan concentration with blood pressure therapeutic response in Chinese hypertensive subjects. Clin. Pharmacol. Ther. 78: 239-48 [PMID:16153395]

213. Jockers R, Issad T, Zilberfarb V, de Coppet P, Marullo S and Strosberg AD. (1998) Desensitization of the beta-adrenergic response in human brown adipocytes. Endocrinology. 139: 2676-2684 [PMID:9607772]

214. Johnson RD and Minneman KP. (1987) Differentiation of $\alpha_{1}$-adrenergic receptors linked to phosphatidylinositol turnover and cyclic AMP accumulation in rat brain. Mol. Pharmacol. 31: 239-246 [PMID:2436033]

215. Joiner ML, Lisé MF, Yuen EY, Kam AY, Zhang M, Hall DD, Malik ZA, Qian H, Chen Y and Ulrich JDet al.. (2010) Assembly of a beta2-adrenergic receptor--GluR1 signalling complex for localized cAMP signalling. EMBO J. 29: 482-95 [PMID:19942860]

216. Jones SB, Halenda SP and Bylund DB. (1991) Alpha 2-adrenergic receptor stimulation of phospholipase A2 and of adenylate cyclase in transfected Chinese hamster ovary cells is mediated by different mechanisms. Mol. Pharmacol. 39: 239-45 [PMID:1847497]

217. Jordan BA, Trapaidze N, Gomes I, Nivarthi R and Devi LA. (2001) Oligomerization of opioid receptors with beta 2-adrenergic receptors: a role in trafficking and mitogen-activated protein kinase activation. Proc. 
Natl. Acad. Sci. U.S.A. 98: 343-8 [PMID:11134510]

218. Joseph SS, Lynham JA, Colledge WH and Kaumann AJ. (2004) Binding of (-)-[3H]-CGP12177 at two sites in recombinant human beta 1-adrenoceptors and interaction with beta-blockers. Naunyn Schmiedebergs Arch. Pharmacol. 369: 525-32 [PMID:15060759]

219. Joseph SS, Lynham JA, Grace AA, Colledge WH and Kaumann AJ. (2004) Markedly reduced effects of ()-isoprenaline but not of (-)-CGP12177 and unchanged affinity of beta-blockers at Gly389-beta1adrenoceptors compared to Arg389-beta1-adrenoceptors. Br. J. Pharmacol. 142: 51-6 [PMID:15037517]

220. Joseph SS, Lynham JA, Molenaar P, Grace AA, Colledge WH and Kaumann AJ. (2003) Intrinsic sympathomimetic activity of (-)-pindolol mediated through a (-)-propranolol-resistant site of the beta1adrenoceptor in human atrium and recombinant receptors. Naunyn Schmiedebergs Arch. Pharmacol. 368: 496-503 [PMID:14608456]

221. Jung $H$, Windhaber R, Palm $D$ and Schnackerz KD. (1995) NMR and circular dichroism studies of synthetic peptides derived from the third intracellular loop of the beta-adrenoceptor. FEBS Lett. 358: 133-6 [PMID:7828722]

222. Kable JW, Murrin LC and Bylund DB. (2000) In vivo gene modification elucidates subtype-specific functions of alpha(2)-adrenergic receptors. J. Pharmacol. Exp. Ther. 293: 1-7 [PMID:10734146]

223. Kaumann AJ. (1997) Four beta-adrenoceptor subtypes in the mammalian heart.Trends Pharmacol. Sci. 18: 70-6 [PMID:9133774]

224. Kaumann AJ, Preitner F, Sarsero D, Molenaar P, Revelli JP and Giacobino JP. (1998) (-)-CGP 12177 causes cardiostimulation and binds to cardiac putative beta 4-adrenoceptors in both wild-type and beta 3adrenoceptor knockout mice. Mol. Pharmacol. 53: 670-5 [PMID:9547357]

225. Kawanabe $Y$, Hashimoto $N$ and Masaki T. (2004) Characterization of $G$ proteins involved in activation of nonselective cation channels and arachidonic acid release by norepinephrine/alpha1A-adrenergic receptors. Am. J. Physiol., Cell Physiol. 286: C596-600 [PMID:14761886]

226. Kennis LE, Bischoff FP, Mertens CJ, Love CJ, Van den Keybus FA, Pieters S, Braeken M, Megens AA and Leysen JE. (2000) New 2-substituted 1,2,3,4-tetrahydrobenzofuro[3,2-c]pyridine having highly active and potent central alpha 2-antagonistic activity as potential antidepressants. Bioorg. Med. Chem. Lett. 10: 71-4 [PMID:10636247]

227. Kenny BA, Chalmers DH, Philpott PC and Naylor AM. (1995) Characterization of an alpha 1Dadrenoceptor mediating the contractile response of rat aorta to noradrenaline. Br. J. Pharmacol. 115: 981-6 [PMID:7582530]

228. Khan MA, Sattar MA, Abdullah NA and Johns EJ. (2008) Alpha1B-adrenoceptors mediate adrenergicallyinduced renal vasoconstrictions in rats with renal impairment. Acta Pharmacol. Sin. 29: 193-203 [PMID:18215348]

229. Khattar SK, Bora RS, Priyadarsiny P, Gautam A, Gupta D, Tiwari A, Nanda K, Singh R, Chugh A and Bansal $V$ et al.. (2006) Molecular cloning, stable expression and cellular localization of human alpha1adrenergic receptor subtypes: effect of charcoal/dextran treated serum on expression and localization of alpha1D -adrenergic receptor. Biotechnol. Lett. 28: 1731-9 [PMID:16912925]

230. Kim TH, Chung KY, Manglik A, Hansen AL, Dror RO, Mildorf TJ, Shaw DE, Kobilka BK and Prosser RS. (2013) The role of ligands on the equilibria between functional states of a $G$ protein-coupled receptor. $J$. Am. Chem. Soc. 135: 9465-74 [PMID:23721409]

231. Kimura K, Sasaki N, Asano A, Mizukami J, Kayahashi S, Kawada T, Fushiki T, Morimatsu M, Yoshida T and Saito M. (2000) Mutated human beta3-adrenergic receptor (Trp64Arg) lowers the response to beta3adrenergic agonists in transfected 3T3-L1 preadipocytes. Horm. Metab. Res. 32: 91-6 [PMID:10786926]

232. Knepper SM, Buckner SA, Brune ME, DeBernardis JF, Meyer MD and Hancock AA. (1995) A-61603, a potent alpha 1-adrenergic receptor agonist, selective for the alpha $1 \mathrm{~A}$ receptor subtype. J. Pharmacol. Exp. Ther. 274: 97-103 [PMID:7616455]

233. Knowlton KU, Michel MC, Itani M, Shubeita HE, Ishihara K, Brown JH and Chien KR. (1993) The alpha $1 \mathrm{~A}$-adrenergic receptor subtype mediates biochemical, molecular, and morphologic features of cultured myocardial cell hypertrophy. J. Biol. Chem. 268: 15374-80 [PMID:8393439] 
234. Kobayashi S, Tomiyama Y, Hoyano Y, Yamazaki Y, Kusama H, Itoh Y, Kubota Y and Kohri K. (2009) Gene expressions and mechanical functions of $\alpha 1$-adrenoceptor subtypes in mouse ureter. World $\mathrm{J}$ Urol 27: 775-80 [PMID:19259685]

235. Kobilka BK, Dixon RA, Frielle T, Dohlman HG, Bolanowski MA, Sigal IS, Yang-Feng TL, Francke U, Caron MG and Lefkowitz RJ. (1987) CDNA for the human beta 2-adrenergic receptor: a protein with multiple membrane-spanning domains and encoded by a gene whose chromosomal location is shared with that of the receptor for platelet-derived growth factor. Proc. Natl. Acad. Sci. U.S.A. 84: 46-50 [PMID:3025863]

236. Kobilka BK, Frielle T, Collins S, Yang-Feng T, Kobilka TS, Francke U, Lefkowitz RJ and Caron MG. (1987) An intronless gene encoding a potential member of the family of receptors coupled to guanine nucleotide regulatory proteins. Nature 329: 75-9 [PMID:3041227]

237. Kobilka BK, Matsui H, Kobilka TS, Yang-Feng TL, Francke U, Caron MG, Lefkowitz RJ and Regan JW. (1987) Cloning, sequencing, and expression of the gene coding for the human platelet alpha 2-adrenergic receptor. Science 238: 650-6 [PMID:2823383]

238. Kobori N, Hu B and Dash PK. (2011) Altered adrenergic receptor signaling following traumatic brain injury contributes to working memory dysfunction. Neuroscience 172: 293-302 [PMID:20974230]

239. Kodama D and Togari A. (2010) Modulation of potassium channels via the $\alpha 1 B$-adrenergic receptor in human osteoblasts. Neurosci. Lett. 485: 102-6 [PMID:20813157]

240. Kohout TA, Takaoka H, McDonald PH, Perry SJ, Mao L, Lefkowitz RJ and Rockman HA. (2001) Augmentation of cardiac contractility mediated by the human beta(3)-adrenergic receptor overexpressed in the hearts of transgenic mice. Circulation 104: 2485-91 [PMID:11705829]

241. Kojima Y, Sasaki S, Kubota Y, Hayase M, Hayashi Y, Shinoura H, Tsujimoto G and Kohri K. (2008) Expression of alpha1-adrenoceptor subtype mRNA as a predictor of the efficacy of subtype selective alpha1-adrenoceptor antagonists in the management of benign prostatic hyperplasia. J. Urol. 179: 1040-6 [PMID:18206918]

242. Kojima Y, Sasaki S, Kubota Y, Imura M, Oda N, Kiniwa M, Hayashi Y and Kohri K. (2011) Up-regulation of $\alpha 1 \mathrm{a}$ and $\alpha 1 \mathrm{~d}$-adrenoceptors in the prostate by administration of subtype selective $\alpha 1$-adrenoceptor antagonist tamsulosin in patients with benign prostatic hyperplasia. J. Urol. 186: 1530-6 [PMID:21855934]

243. Kompa AR and Summers RJ. (1999) Desensitization and resensitization of beta 1- and putative beta 4adrenoceptor mediated responses occur in parallel in a rat model of cardiac failure. Br. J. Pharmacol. 128: 1399-406 [PMID:10602318]

244. Konkar AA, Zhai $Y$ and Granneman JG. (2000) $\beta 1$-Adrenergic receptors mediate $\beta 3$-adrenergicindependent effects of CGP 12177 in Brown Adipose Tissue. Mol. Pharmacol. 57: 252-258 [PMID:10648634]

245. Koshimizu TA, Tanoue A, Hirasawa A, Yamauchi J and Tsujimoto G. (2003) Recent advances in alpha1adrenoceptor pharmacology. Pharmacol. Ther. 98: 235-44 [PMID:12725871]

246. Koshimizu TA, Tsujimoto G, Hirasawa A, Kitagawa Y and Tanoue A. (2004) Carvedilol selectively inhibits oscillatory intracellular calcium changes evoked by human alpha1D- and alpha1B-adrenergic receptors. Cardiovasc. Res. 63: 662-72 [PMID:15306222]

247. Krief S, Lonnqvist F, Raimbault S, Baude B, Van Spronsen A, Arner P, Strosberg AD, Ricquier D and Emorine LJ. (1993) Tissue distribution of beta 3-adrenergic receptor mRNA in man. J Clin Invest. 91: 344349 [PMID:8380813]

248. Krushinski Jr JH, Schaus JM, Thompson DC, Calligaro DO, Nelson DL, Luecke SH, Wainscott DB and Wong DT. (2007) Indoloxypropanolamine analogues as 5-HT(1A) receptor antagonists. Bioorg. Med. Chem. Lett. 17: 5600-4 [PMID:17804228]

249. Kunieda T, Zuscik MJ, Boongird A, Perez DM, Lüders HO and Najm IM. (2002) Systemic overexpression of the alpha 1B-adrenergic receptor in mice: an animal model of epilepsy. Epilepsia 43: 1324-9 [PMID:12423381]

250. Kuravi S, Lan TH, Barik A and Lambert NA. (2010) Third-party bioluminescence resonance energy transfer indicates constitutive association of membrane proteins: application to class a g-protein-coupled receptors and g-proteins. Biophys. J. 98: 2391-9 [PMID:20483349] 
251. Lakhlani PP, Amenta F, Napoleone P, Felici L and Eikenburg DC. (1994) Pharmacological characterization and anatomical localization of prejunctional beta-adrenoceptors in the rat kidney. $\mathrm{Br} J$ Pharmacol 111: 1296-1308 [PMID:8032617]

252. Lakhlani PP, MacMillan LB, Guo TZ, McCool BA, Lovinger DM, Maze M and Limbird LE. (1997) Substitution of a mutant alpha2a-adrenergic receptor via "hit and run" gene targeting reveals the role of this subtype in sedative, analgesic, and anesthetic-sparing responses in vivo. Proc. Natl. Acad. Sci. U.S.A. 94: 9950-5 [PMID:9275232]

253. Lands AM, Arnold A, McAuliff JP, Luduena FP and Brown Jr TG. (1967) Differentiation of receptor systems activated by sympathomimetic amines. Nature 214: 597-8 [PMID:6036174]

254. Lanier SM, Downing S, Duzic E and Homcy CJ. (1991) Isolation of rat genomic clones encoding subtypes of the alpha 2-adrenergic receptor. Identification of a unique receptor subtype. J. Biol. Chem. 266: 10470-8 [PMID:1645350]

255. Large V, Arner P, Reynisdottir S, Grober J, Van Harmelen V, Holm C and Langin D. (1998) Hormonesensitive lipase expression and activity in relation to lipolysis in human fat cells. $J$ Lipid Res. 39: 1688-1695 [PMID:9717730]

256. LaRocca TJ, Schwarzkopf M, Altman P, Zhang S, Gupta A, Gomes I, Alvin Z, Champion HC, Haddad G and Hajjar RJ et al.. (2010) $\beta 2$-Adrenergic receptor signaling in the cardiac myocyte is modulated by interactions with CXCR4. J. Cardiovasc. Pharmacol. 56: 548-59 [PMID:20729750]

257. Lavoie $C$ and Hébert TE. (2003) Pharmacological characterization of putative beta1-beta2-adrenergic receptor heterodimers. Can. J. Physiol. Pharmacol. 81: 186-95 [PMID:12710533]

258. Lavoie C, Mercier JF, Salahpour A, Umapathy D, Breit A, Villeneuve LR, Zhu WZ, Xiao RP, Lakatta EG and Bouvier $\mathrm{M}$ et al.. (2002) Beta 1/beta 2-adrenergic receptor heterodimerization regulates beta 2adrenergic receptor internalization and ERK signaling efficacy. J. Biol. Chem. 277: 35402-10 [PMID:12140284]

259. Lee D, Robeva A, Chen $Z$ and Minneman KP. (2003) Mutational uncoupling of alpha1A-adrenergic receptors from $G$ proteins also uncouples mitogenic and transcriptional responses in PC12 cells. J. Pharmacol. Exp. Ther. 306: 471-7 [PMID:12724349]

260. Leech CJ and Faber JE. (1996) Different alpha-adrenoceptor subtypes mediate constriction of arterioles and venules. Am. J. Physiol. 270: H710-22 [PMID:8779849]

261. Leineweber K, Büscher R, Bruck H and Brodde OE. (2004) Beta-adrenoceptor polymorphisms. Naunyn Schmiedebergs Arch. Pharmacol. 369: 1-22 [PMID:14647973]

262. Leiphart JW, Dills CV and Levy RM. (2004) Alpha2-adrenergic receptor subtype specificity of intrathecally administered tizanidine used for analgesia for neuropathic pain. J. Neurosurg. 101: 641-7 [PMID:15481719]

263. Lelias JM, Kaghad M, Rodriguez M, Chalon P, Bonnin J, Dupre I, Delpech B, Bensaid M, LeFur G and Ferrara $\mathrm{P}$ et al.. (1993) Molecular cloning of a human beta 3-adrenergic receptor cDNA.FEBS Lett. 324: 127-30 [PMID:8389717]

264. Leonardi A, Hieble JP, Guarneri L, Naselsky DP, Poggesi E, Sironi G, Sulpizio AC and Testa R. (1997) Pharmacological characterization of the uroselective alpha-1 antagonist Rec 15/2739 (SB 216469): role of the alpha-1L adrenoceptor in tissue selectivity, part I. J. Pharmacol. Exp. Ther. 281: 1272-83 [PMID:9190863]

265. Leppik RA, Lazareno S, Mynett A and Birdsall NJ. (1998) Characterization of the allosteric interactions between antagonists and amiloride analogues at the human alpha2A-adrenergic receptor. Mol. Pharmacol. 53: 916-25 [PMID:9584219]

266. Li F, De Godoy M and Rattan S. (2004) Role of adenylate and guanylate cyclases in beta1-, beta2-, and beta3-adrenoceptor-mediated relaxation of internal anal sphincter smooth muscle. J. Pharmacol. Exp. Ther. 308: 1111-20 [PMID:14711933]

267. Li YF, Cao XJ, Bai XY, Lin SP and Shi ST. (2010) Change of expression of renal alpha1-adrenergic receptor and angiotensin II receptor subtypes with aging in rats. Aging Clin Exp Res 22: 123-8 [PMID:20440098] 
268. Liapakis G, Chan WC, Papadokostaki M and Javitch JA. (2004) Synergistic contributions of the functional groups of epinephrine to its affinity and efficacy at the beta2 adrenergic receptor. Mol. Pharmacol. 65: 1181-90 [PMID:15102946]

269. Liggett SB. (2003) Polymorphisms of adrenergic receptors: variations on a theme.Assay Drug Dev Technol 1: 317-26 [PMID:15090197]

270. Lima V, Mueller A, Kamikihara SY, Raymundi V, Alewood D, Lewis RJ, Chen Z, Minneman KP and Pupo AS. (2005) Differential antagonism by conotoxin rho-TIA of contractions mediated by distinct alpha1adrenoceptor subtypes in rat vas deferens, spleen and aorta. Eur. J. Pharmacol. 508: 183-92 [PMID:15680270]

271. Limbird LE. (1988) Receptors linked to inhibition of adenylate cyclase: additional signaling mechanisms. FASEB J. 2: 2686-95 [PMID:2840317]

272. Lin F, Owens WA, Chen S, Stevens ME, Kesteven S, Arthur JF, Woodcock EA, Feneley MP and Graham RM. (2001) Targeted alpha(1A)-adrenergic receptor overexpression induces enhanced cardiac contractility but not hypertrophy. Circ. Res. 89: 343-50 [PMID:11509451]

273. Link R, Daunt D, Barsh G, Chruscinski A and Kobilka B. (1992) Cloning of two mouse genes encoding alpha 2-adrenergic receptor subtypes and identification of a single amino acid in the mouse alpha 2-C10 homolog responsible for an interspecies variation in antagonist binding. Mol. Pharmacol. 42: 16-27 [PMID:1353249]

274. Link RE, Desai K, Hein L, Stevens ME, Chruscinski A, Bernstein D, Barsh GS and Kobilka BK. (1996) Cardiovascular regulation in mice lacking alpha2-adrenergic receptor subtypes b and c. Science 273: 8035 [PMID:8670422]

275. Liu CM, Lo YC, Wu BN, Wu WJ, Chou YH, Huang CH, An LM and Chen IJ. (2007) cGMP-enhancing- and alpha1A/alpha1D-adrenoceptor blockade-derived inhibition of Rho-kinase by KMUP-1 provides optimal prostate relaxation and epithelial cell anti-proliferation efficacy. Prostate 67: 1397-410 [PMID:17639498]

276. Liu F, He K, Yang X, Xu N, Liang Z, Xu M, Zhao X, Han Q and Zhang Y. (2011) \&1A-adrenergic receptor induces activation of extracellular signal-regulated kinase $1 / 2$ through endocytic pathway. PLOS ONE 6: e21520 [PMID:21738688]

277. Liu JJ, Horst R, Katritch V, Stevens RC and Wüthrich K. (2012) Biased signaling pathways in $\beta 2$ adrenergic receptor characterized by 19F-NMR. Science 335: 1106-10 [PMID:22267580]

278. Liu YL, Nwosu UC and Rice PJ. (1998) Relaxation of isolated human myometrial muscle by beta2adrenergic receptors but not beta1-adrenergic receptors. Am. J. Obstet. Gynecol. 179: 895-8 [PMID:9790366]

279. Lomasney JW, Cotecchia S, Lorenz W, Leung WY, Schwinn DA, Yang-Feng TL, Brownstein M, Lefkowitz RJ and Caron MG. (1991) Molecular cloning and expression of the cDNA for the alpha 1A-adrenergic receptor. The gene for which is located on human chromosome 5. J. Biol. Chem. 266: 6365-9 [PMID:1706716]

280. Lonnqvist F, Krief S, Strosberg AD, Nyberg S, Emorine LJ and Arner P. (1993) Evidence for a functional beta 3-adrenoceptor in man. Br J Pharmacol. 110: 929-936 [PMID:7905344]

281. Louis SN, Nero TL, lakovidis D, Jackman GP and Louis WJ. (1999) LK 204-545, a highly selective beta1adrenoceptor antagonist at human beta-adrenoceptors. Eur. J. Pharmacol. 367: 431-5 [PMID:10079020]

282. Lyssand JS, DeFino MC, Tang XB, Hertz AL, Feller DB, Wacker JL, Adams ME and Hague C. (2008) Blood pressure is regulated by an alpha1D-adrenergic receptor/dystrophin signalosome. J. Biol. Chem. 283: 18792-800 [PMID:18468998]

283. Lyssand JS, Lee KS, DeFino M, Adams ME and Hague C. (2011) Syntrophin isoforms play specific functional roles in the $\alpha 1 \mathrm{D}$-adrenergic receptor/DAPC signalosome. Biochem. Biophys. Res. Commun. 412: 596-601 [PMID:21846462]

284. Lyssand JS, Whiting JL, Lee KS, Kastl R, Wacker JL, Bruchas MR, Miyatake M, Langeberg LK, Chavkin C and Scott JD et al.. (2010) Alpha-dystrobrevin-1 recruits alpha-catulin to the alpha1D-adrenergic receptor/dystrophin-associated protein complex signalosome. Proc. Natl. Acad. Sci. U.S.A. 107: 21854-9 [PMID:21115837] 
285. MacDonald E, Kobilka BK and Scheinin M. (1997) Gene targeting--homing in on alpha 2-adrenoceptorsubtype function. Trends Pharmacol. Sci. 18: 211-9 [PMID:9227000]

286. Machida CA, Bunzow JR, Searles RP, Van Tol H, Tester B, Neve KA, Teal P, Nipper V and Civelli O. (1990) Molecular cloning and expression of the rat beta 1-adrenergic receptor gene. J. Biol. Chem. 265: 12960-5 [PMID:1695899]

287. Mackenzie JF, Daly CJ, Pediani JD and McGrath JC. (2000) Quantitative imaging in live human cells reveals intracellular alpha(1)-adrenoceptor ligand-binding sites. J. Pharmacol. Exp. Ther. 294: 434-43 [PMID:10900216]

288. MacLennan SJ, Luong LA, Jasper JR, To ZP and Eglen RM. (1997) Characterization of alpha 2adrenoceptors mediating contraction of dog saphenous vein: identity with the human alpha $2 \mathrm{~A}$ subtype. $\mathrm{Br}$. J. Pharmacol. 121: 1721-9 [PMID:9283709]

289. MacMillan LB, Hein L, Smith MS, Piascik MT and Limbird LE. (1996) Central hypotensive effects of the alpha2a-adrenergic receptor subtype. Science 273: 801-3 [PMID:8670421]

290. Makaritsis KP, Handy DE, Johns C, Kobilka B, Gavras I and Gavras H. (1999) Role of the alpha2Badrenergic receptor in the development of salt-induced hypertension. Hypertension 33: 14-7 [PMID:9931075]

291. Malloy BJ, Price DT, Price RR, Bienstock AM, Dole MK, Funk BL, Rudner XL, Richardson CD, Donatucci CF and Schwinn DA. (1998) Alpha1-adrenergic receptor subtypes in human detrusor. J. Urol. 160: 937-43 [PMID:9720591]

292. Manglik A, Kim TH, Masureel M, Altenbach C, Yang Z, Hilger D, Lerch MT, Kobilka TS, Thian FS and Hubbell WL et al.. (2015) Structural Insights into the Dynamic Process of $\beta 2$-Adrenergic Receptor Signaling. Cell 161: 1101-11 [PMID:25981665]

293. Maqbool A, Hall AS, Ball SG and Balmforth AJ. (1999) Common polymorphisms of beta1-adrenoceptor: identification and rapid screening assay. Lancet 353: 897 [PMID:10093986]

294. Mason DA, Moore JD, Green SA and Liggett SB. (1999) A gain-of-function polymorphism in a G-protein coupling domain of the human beta1-adrenergic receptor. J. Biol. Chem. 274: 12670-4 [PMID:10212248]

295. Matsushita M, Horinouchi T, Tanaka Y, Tsuru H and Koike K. (2003) Characterization of beta 3adrenoceptor-mediated relaxation in rat abdominal aorta smooth muscle. Eur. J. Pharmacol. 482: 235-44 [PMID:14660028]

296. Maudsley S, Pierce KL, Zamah AM, Miller WE, Ahn S, Daaka Y, Lefkowitz RJ and Luttrell LM. (2000) The beta(2)-adrenergic receptor mediates extracellular signal-regulated kinase activation via assembly of a multi-receptor complex with the epidermal growth factor receptor. J. Biol. Chem. 275: 9572-80 [PMID:10734107]

297. Maïga A, Merlin J, Marcon E, Rouget C, Larregola M, Gilquin B, Fruchart-Gaillard C, Lajeunesse E, Marchetti $C$ and Lorphelin A et al.. (2013) Orthosteric binding of $\rho$-Da1a, a natural peptide of snake venom interacting selectively with the $\alpha 1 \mathrm{~A}$-adrenoceptor. PLoS ONE 8: e68841 [PMID:23935897]

298. McCune D, Gaivin R, Rorabaugh B and Perez D. (2004) Bulk is a determinant of oxymetazoline affinity for the alpha1A-adrenergic receptor. Recept. Channels 10: 109-16 [PMID:15512845]

299. McGraw DW, Forbes SL, Kramer LA, Witte DP, Fortner CN, Paul RJ and Liggett SB. (1999) Transgenic overexpression of beta(2)-adrenergic receptors in airway smooth muscle alters myocyte function and ablates bronchial hyperreactivity. J. Biol. Chem. 274: 32241-7 [PMID:10542262]

300. McGraw DW, Mihlbachler KA, Schwarb MR, Rahman FF, Small KM, Almoosa KF and Liggett SB. (2006) Airway smooth muscle prostaglandin-EP1 receptors directly modulate beta2-adrenergic receptors within a unique heterodimeric complex. J. Clin. Invest. 116: 1400-9 [PMID:16670773]

301. McVey M, Ramsay D, Kellett E, Rees S, Wilson S, Pope AJ and Milligan G. (2001) Monitoring receptor oligomerization using time-resolved fluorescence resonance energy transfer and bioluminescence resonance energy transfer. The human delta -opioid receptor displays constitutive oligomerization at the cell surface, which is not regulated by receptor occupancy. J. Biol. Chem. 276: 14092-9 [PMID:11278447]

302. Melis MG, Secchi G, Brizzi P, Severino C, Maioli M and Tonolo G. (2002) The Trp64Arg beta3-adrenergic receptor amino acid variant confers increased sensitivity to the pressor effects of noradrenaline in 
Sardinian subjects. Clin. Sci. 103: 397-402 [PMID:12241539]

303. Mendes FR, Hamamura M, Queiróz DB, Porto CS and Avellar MC. (2004) Effects of androgen manipulation on alpha1-adrenoceptor subtypes in the rat seminal vesicle. Life Sci. 75: 1449-63 [PMID:15240180]

304. Mercier JF, Salahpour A, Angers S, Breit A and Bouvier M. (2002) Quantitative assessment of beta 1- and beta 2-adrenergic receptor homo- and heterodimerization by bioluminescence resonance energy transfer. J. Biol. Chem. 277: 44925-31 [PMID:12244098]

305. Methven L, McBride M, Wallace GA and McGrath JC. (2009) The alpha 1B/D-adrenoceptor knockout mouse permits isolation of the vascular alpha $1 \mathrm{~A}$-adrenoceptor and elucidates its relationship to the other subtypes. Br. J. Pharmacol. 158: 209-24 [PMID:19572943]

306. Methven L, Simpson PC and McGrath JC. (2009) Alpha1A/B-knockout mice explain the native alpha1Dadrenoceptor's role in vasoconstriction and show that its location is independent of the other alpha1subtypes. Br. J. Pharmacol. 158: 1663-75 [PMID:19888965]

307. Meyer MD, Altenbach RJ, Basha FZ, Carroll WA, Drizin I, Elmore SW, Ehrlich PP, Lebold SA, Tietje K and Sippy KB et al.. (1997) Synthesis and pharmacological characterization of 3-[2-((3aR,9bR)-cis-6-methoxy2,3,3a,4,5,9b-hexahydro-1H-benz[e] isoindol-2-yl)ethyl]pyrido-[3',4':4,5]thieno[3,2-d]pyrimidine-2,4 $(1 \mathrm{H}, 3 \mathrm{H})$-dione $(\mathrm{A}-131701)$ : a uroselective alpha $1 \mathrm{~A}$ adrenoceptor antagonist for the symptomatic treatment of benign prostatic hyperplasia. J. Med. Chem. 40: 3141-3 [PMID:9379432]

308. Mhaouty-Kodja S, Lozach A, Habert R, Tanneux M, Guigon C, Brailly-Tabard S, Maltier JP and LegrandMaltier C. (2007) Fertility and spermatogenesis are altered in \{alpha\}1b-adrenergic receptor knockout male mice. J. Endocrinol. 195: 281-92 [PMID:17951539]

309. Michel AD, Loury DN and Whiting RL. (1990) Assessment of imiloxan as a selective alpha 2Badrenoceptor antagonist. Br. J. Pharmacol. 99: 560-4 [PMID:1970500]

310. Michel AD, Loury DN and Whiting RL. (1989) Differences between the alpha 2-adrenoceptor in rat submaxillary gland and the alpha 2A-and alpha 2B-adrenoceptor subtypes. Br. J. Pharmacol. 98: 890-7 [PMID:2556205]

311. Michelotti GA, Brinkley DM, Morris DP, Smith MP, Louie RJ and Schwinn DA. (2007) Epigenetic regulation of human alpha1d-adrenergic receptor gene expression: a role for DNA methylation in Sp1-dependent regulation. FASEB J. 21: 1979-93 [PMID:17384146]

312. Michelotti GA, Price DT and Schwinn DA. (2000) Alpha 1-adrenergic receptor regulation: basic science and clinical implications. Pharmacol. Ther. 88: 281-309 [PMID:11337028]

313. Millan MJ, Maiofiss L, Cussac D, Audinot V, Boutin JA and Newman-Tancredi A. (2002) Differential actions of antiparkinson agents at multiple classes of monoaminergic receptor. I. A multivariate analysis of the binding profiles of 14 drugs at 21 native and cloned human receptor subtypes. J. Pharmacol. Exp. Ther. 303: 791-804 [PMID:12388666]

314. Minarini A, Budriesi R, Chiarini A, Leonardi A and Melchiorre C. (1998) Search for alpha 1-adrenoceptor subtypes selective antagonists: design, synthesis and biological activity of cystazosin, an alpha 1Dadrenoceptor antagonist. Bioorg. Med. Chem. Lett. 8: 1353-8 [PMID:9871765]

315. Minneman KP, Han $C$ and Abel PW. (1988) Comparison of $\alpha_{4}$-adrenergic receptor subtypes distinguished by chloroethylclonidine and WB4101. Mol. Pharmacol. 33: 509-514 [PMID:2835650]

316. Minneman KP, Hegstrand LR and Molinoff PB. (1979) The pharmacological specificity of beta-1 and beta2 adrenergic receptors in rat heart and lung in vitro. Mol. Pharmacol. 16: 21-33 [PMID:39243]

317. Minneman KP, Theroux TL, Hollinger S, Han C and Esbenshade TA. (1994) Selectivity of agonists for cloned alpha 1-adrenergic receptor subtypes. Mol. Pharmacol. 46: 929-36 [PMID:7969082]

318. Mishima K, Tanoue A, Tsuda M, Hasebe N, Fukue Y, Egashira N, Takano Y, Kamiya HO, Tsujimoto G and Iwasaki $\mathrm{K}$ et al.. (2004) Characteristics of behavioral abnormalities in alpha1d-adrenoceptors deficient mice. Behav. Brain Res. 152: 365-73 [PMID:15196805]

319. Mizusawa H, Hedlund P, Sjunnesson J, Brioni JD, Sullivan JP and Andersson KE. (2002) Enhancement of apomorphine-induced penile erection in the rat by a selective alpha(1D)-adrenoceptor antagonist. Br. J. Pharmacol. 136: 701-8 [PMID:12086979] 
320. Mohl MC, lismaa SE, Xiao XH, Friedrich O, Wagner S, Nikolova-Krstevski V, Wu J, Yu ZY, Feneley M and Fatkin $D$ et al.. (2011) Regulation of murine cardiac contractility by activation of $\alpha(1 \mathrm{~A})$-adrenergic receptoroperated $\mathrm{Ca}(2+)$ entry. Cardiovasc. Res. 91: 310-9 [PMID:21546445]

321. Molderings GJ and Göthert M. (1995) Subtype determination of presynaptic alpha 2-autoreceptors in the rabbit pulmonary artery and human saphenous vein. Naunyn Schmiedebergs Arch. Pharmacol. 352: 48390 [PMID:8751076]

322. Molenaar P, Sarsero D, Arch JR, Kelly J, Henson SM and Kaumann AJ. (1997) Effects of (-)-RO363 at human atrial beta-adrenoceptor subtypes, the human cloned beta 3-adrenoceptor and rodent intestinal beta 3-adrenoceptors. Br. J. Pharmacol. 120: 165-76 [PMID:9117106]

323. Molina-Muñoz T, Romero-Avila MT, Avendaño-Vázquez SE and García-Sáinz JA. (2008) Phosphorylation, desensitization and internalization of human alpha1B-adrenoceptors induced by insulin-like growth factor-I. Eur. J. Pharmacol. 578: 1-10 [PMID:17915215]

324. Morishima S, Tanaka T, Yamamoto H, Suzuki F, Akino H, Yokoyama O and Muramatsu I. (2007) Identification of alpha-1 $\mathrm{L}$ and alpha-1A adrenoceptors in human prostate by tissue segment binding. $J$. Urol. 177: 377-81 [PMID:17162094]

325. Morris DP, Price RR, Smith MP, Lei B and Schwinn DA. (2004) Cellular trafficking of human alpha1aadrenergic receptors is continuous and primarily agonist-independent. Mol. Pharmacol. 66: 843-54 [PMID:15258254]

326. Morrow AL and Creese I. (1986) Characterization of alpha 1-adrenergic receptor subtypes in rat brain: a reevaluation of [3H]WB4104 and [3H]prazosin binding. Mol. Pharmacol. 29: 321-30 [PMID:3010073]

327. Moukhametzianov R, Warne T, Edwards PC, Serrano-Vega MJ, Leslie AG, Tate CG and Schertler GF. (2011) Two distinct conformations of helix 6 observed in antagonist-bound structures of a beta1-adrenergic receptor. Proc. Natl. Acad. Sci. U.S.A. 108: 8228-32 [PMID:21540331]

328. Munk SA, Harcourt D, Ambrus G, Denys L, Gluchowski C, Burke JA, Kharlamb AB, Manlapaz CA, Padillo $\mathrm{EU}$ and Runde $\mathrm{E}$ et al.. (1996) Synthesis and evaluation of 2-[(5-methylbenz-1-ox-4-azin-6yl)imino]imidazoline, a potent, peripherally acting alpha 2 adrenoceptor agonist. J. Med. Chem. 39: 3533-8 [PMID:8784451]

329. Muramatsu I, Ohmura T, Hashimoto S and Oshita M. (1995) Functional subclassification of vascular $q-$ adrenoceptors. Pharmacol. Commun. 6: 23-28

330. Muramatsu I, Oshita M, Ohmura T, Kigoshi S, Akino H, Gobara M and Okada K. (1994) Pharmacological characterization of alpha 1-adrenoceptor subtypes in the human prostate: functional and binding studies. Br J Urol 74: 572-8 [PMID:7530120]

331. Murphy TJ and Bylund DB. (1988) Characterization of alpha-2 adrenergic receptors in the OK cell, an opossum kidney cell line. J. Pharmacol. Exp. Ther. 244: 571-8 [PMID:2894455]

332. Muzzin P, Revelli JP, Kuhne F, Gocayne JD, McCombie WR, Venter JC, Giacobino JP and Fraser CM. (1991) An adipose tissue-specific beta-adrenergic receptor. Molecular cloning and down-regulation in obesity. J. Biol. Chem. 266: 24053-8 [PMID:1721063]

333. Méjean A, Guillaume JL and Strosberg AD. (1995) Carazolol: a potent, selective beta 3-adrenoceptor agonist. Eur. J. Pharmacol. 291: 359-66 [PMID:8719421]

334. Nagaoka $Y$, Ahmed M, Hossain M, Bhuiyan MA, Ishiguro M, Nakamura T, Watanabe M and Nagatomo T. (2008) Amino acids of the human alpha1d-adrenergic receptor involved in antagonist binding. $J$. Pharmacol. Sci. 106: 114-20 [PMID:18187928]

335. Nahmias C, Blin N, Elalouf JM, Mattei MG, Strosberg AD and Emorine LJ. (1991) Molecular characterization of the mouse beta 3-adrenergic receptor: relationship with the atypical receptor of adipocytes. EMBO J. 10: 3721-7 [PMID:1718744]

336. Nalepa I, Vetulani J, Borghi V, Kowalska M, Przewłocka B and Pavone F. (2005) Formalin hindpaw injection induces changes in the [3H]prazosin binding to alpha1-adrenoceptors in specific regions of the mouse brain and spinal cord. J Neural Transm 112: 1309-19 [PMID:15719155]

337. Neubig RR, Gantzos RD and Brasier RS. (1985) Agonist and antagonist binding to alpha 2-adrenergic receptors in purified membranes from human platelets. Implications of receptor-inhibitory nucleotide- 
binding protein stoichiometry. Mol. Pharmacol. 28: 475-86 [PMID:2865672]

338. Nicholas AP, Hökfelt T and Pieribone VA. (1996) The distribution and significance of CNS adrenoceptors examined with in situ hybridization. Trends Pharmacol. Sci. 17: 245-55 [PMID:8756183]

339. Nicholson R, Dixon AK, Spanswick D and Lee K. (2005) Noradrenergic receptor mRNA expression in adult rat superficial dorsal horn and dorsal root ganglion neurons. Neurosci. Lett. 380: 316-21 [PMID:15862909]

340. Nonen S, Okamoto H, Fujio Y, Takemoto Y, Yoshiyama M, Hamaguchi T, Matsui Y, Yoshikawa J, Kitabatake A and Azuma J. (2008) Polymorphisms of norepinephrine transporter and adrenergic receptor alpha1D are associated with the response to beta-blockers in dilated cardiomyopathy. Pharmacogenomics J. 8: 78-84 [PMID:17404580]

341. Nourian Z, Mow T, Muftic D, Burek S, Pedersen ML, Matz J and Mulvany MJ. (2008) Orthostatic hypotensive effect of antipsychotic drugs in Wistar rats by in vivo and in vitro studies of alpha1adrenoceptor function. Psychopharmacology (Berl.) 199: 15-27 [PMID:18542932]

342. Nygaard R, Zou Y, Dror RO, Mildorf TJ, Arlow DH, Manglik A, Pan AC, Liu CW, Fung JJ and Bokoch MP et al.. (2013) The dynamic process of $\beta(2)$-adrenergic receptor activation. Cell 152: 532-42 [PMID:23374348]

343. O'Rourke MF, Iversen LJ, Lomasney JW and Bylund DB. (1994) Species orthologs of the alpha-2A adrenergic receptor: the pharmacological properties of the bovine and rat receptors differ from the human and porcine receptors. J. Pharmacol. Exp. Ther. 271: 735-40 [PMID:7965790]

344. Obika K, Shibata K, Horie K, Foglar R, Kimura K and Tsujimoto G. (1995) NS-49, a novel alpha 1aadrenoceptor-selective agonist characterization using recombinant human alpha 1-adrenoceptors. Eur. J. Pharmacol. 291: 327-34 [PMID:8719417]

345. Ochoa MC, Marti A, Azcona C, Chueca M, Oyarzábal M, Pelach R, Patiño A, Moreno-Aliaga MJ, MartínezGonzález MA and Martínez JA et al.. (2004) Gene-gene interaction between PPAR gamma 2 and ADR beta 3 increases obesity risk in children and adolescents. Int. J. Obes. Relat. Metab. Disord. 28 Suppl 3: S37-41 [PMID:15543217]

346. Ohmura T, Oshita M, Kigoshi S and Muramatsu I. (1992) Identification of alpha 1-adrenoceptor subtypes in the rat vas deferens: binding and functional studies. Br. J. Pharmacol. 107: 697-704 [PMID:1361871]

347. Oostendorp J, Preitner F, Moffatt J, Jimenez M, Giacobino JP, Molenaar P and Kaumann AJ. (2000) Contribution of beta-adrenoceptor subtypes to relaxation of colon and oesophagus and pacemaker activity of ureter in wildtype and beta(3)-adrenoceptor knockout mice. Br. J. Pharmacol. 130: 747-58 [PMID:10864880]

348. Oshita M, Kigoshi S and Muramatsu I. (1991) Three distinct binding sites for [3H]-prazosin in the rat cerebral cortex. Br. J. Pharmacol. 104: 961-5 [PMID:1687370]

349. Ozdoğan UK, Lähdesmäki J, Mansikka H and Scheinin M. (2004) Loss of amitriptyline analgesia in alpha 2A-adrenoceptor deficient mice. Eur. J. Pharmacol. 485: 193-6 [PMID:14757140]

350. Papay R, Gaivin R, Jha A, McCune DF, McGrath JC, Rodrigo MC, Simpson PC, Doze VA and Perez DM. (2006) Localization of the mouse alpha1A-adrenergic receptor (AR) in the brain: alpha1AAR is expressed in neurons, GABAergic interneurons, and NG2 oligodendrocyte progenitors. J. Comp. Neurol. 497: 209-22 [PMID:16705673]

351. Papay R, Gaivin R, McCune DF, Rorabaugh BR, Macklin WB, McGrath JC and Perez DM. (2004) Mouse alpha1B-adrenergic receptor is expressed in neurons and NG2 oligodendrocytes. J. Comp. Neurol. 478: 110 [PMID:15334645]

352. Papay R, Zuscik MJ, Ross SA, Yun J, McCune DF, Gonzalez-Cabrera P, Gaivin R, Drazba J and Perez DM. (2002) Mice expressing the alpha(1B)-adrenergic receptor induces a synucleinopathy with excessive tyrosine nitration but decreased phosphorylation. J. Neurochem. 83: 623-34 [PMID:12390524]

353. Papay RS, Shi T, Piascik MT, Naga Prasad SV and Perez DM. (2013) $\alpha_{1} A$-adrenergic receptors regulate cardiac hypertrophy in vivo through interleukin-6 secretion. Mol. Pharmacol. 83: 939-48 [PMID:23404509]

354. Parkman HP, Jacobs MR, Mishra A, Hurdle JA, Sachdeva P, Gaughan JP and Krynetskiy E. (2011) Domperidone treatment for gastroparesis: demographic and pharmacogenetic characterization of clinical efficacy and side-effects. Dig. Dis. Sci. 56: 115-24 [PMID:21063774] 
355. Parmentier JH, Gandhi GK, Wiggins MT, Saeed AE, Bourgoin SG and Malik KU. (2004) Protein kinase Czeta regulates phospholipase $D$ activity in rat-1 fibroblasts expressing the alpha1 $A$ adrenergic receptor. BMC Cell Biol. 5: 4 [PMID:14736339]

356. Patane MA, Scott AL, Broten TP, Chang RS, Ransom RW, DiSalvo J, Forray C and Bock MG. (1998) 4Amino-2-[4-[1-(benzyloxycarbonyl)-2(S)- [[(1,1-dimethylethyl)amino]carbonyl]-piperazinyl]-6, 7dimethoxyquinazoline (L-765,314): a potent and selective alpha1b adrenergic receptor antagonist. J. Med. Chem. 41: 1205-8 [PMID:9548811]

357. Paton DM. (1976) Adrenergic innervation of the oviduct in the regulation of ovum transportRes Reprod 8 : 3 [PMID:1251089]

358. Pauwels PJ, Gommeren W, Van Lommen G, Janssen PA and Leysen JE. (1988) The receptor binding profile of the new antihypertensive agent nebivolol and its stereoisomers compared with various betaadrenergic blockers. Mol. Pharmacol. 34: 843-51 [PMID:2462161]

359. Pauwels PJ, Rauly I and Wurch T. (2003) Dissimilar pharmacological responses by a new series of imidazoline derivatives at precoupled and ligand-activated alpha 2A-adrenoceptor states: evidence for effector pathway-dependent differential antagonism. J. Pharmacol. Exp. Ther. 305: 1015-23 [PMID:12649300]

360. Peltonen JM, Pihlavisto M and Scheinin M. (1998) Subtype-specific stimulation of [35S]GTPgammaS binding by recombinant alpha2-adrenoceptors. Eur. J. Pharmacol. 355: 275-9 [PMID:9760042]

361. Perez DM, Piascik MT and Graham RM. (1991) Solution-phase library screening for the identification of rare clones: isolation of an alpha 1D-adrenergic receptor cDNA. Mol. Pharmacol. 40: 876-83 [PMID:1661838]

362. Perälä M, Hirvonen H, Kalimo H, Ala-Uotila S, Regan JW, Akerman KE and Scheinin M. (1992) Differential expression of two alpha 2-adrenergic receptor subtype mRNAs in human tissues. Brain Res. Mol. Brain Res. 16: 57-63 [PMID:1334200]

363. Petrovska R, Kapa I, Klovins J, Schiöth HB and Uhlén S. (2005) Addition of a signal peptide sequence to the alpha1D-adrenoceptor gene increases the density of receptors, as determined by [3H]-prazosin binding in the membranes. Br. J. Pharmacol. 144: 651-9 [PMID:15678090]

364. Piascik MT, Guarino RD, Smith MS, Soltis EE, Saussy Jr DL and Perez DM. (1995) The specific contribution of the novel alpha-1D adrenoceptor to the contraction of vascular smooth muscle. $J$. Pharmacol. Exp. Ther. 275: 1583-9 [PMID:8531132]

365. Piascik MT, Hrometz SL, Edelmann SE, Guarino RD, Hadley RW and Brown RD. (1997) Immunocytochemical localization of the alpha-1B adrenergic receptor and the contribution of this and the other subtypes to vascular smooth muscle contraction: analysis with selective ligands and antisense oligonucleotides. J. Pharmacol. Exp. Ther. 283: 854-68 [PMID:9353407]

366. Pihlavisto M, Sjöholm B, Scheinin M and Wurster S. (1998) Modulation of agonist binding to recombinant human alpha2-adrenoceptors by sodium ions. Biochim. Biophys. Acta 1448: 135-46 [PMID:9824686]

367. Piletz JE, Zhu H and Chikkala DN. (1996) Comparison of ligand binding affinities at human I1-imidazoline binding sites and the high affinity state of alpha-2 adrenoceptor subtypes. J. Pharmacol. Exp. Ther. 279: 694-702 [PMID:8930173]

368. Piétri-Rouxel F, Lenzen G, Kapoor A, Drumare MF, Archimbault P, Strosberg AD and Manning BS. (1995) Molecular cloning and pharmacological characterization of the bovine beta 3-adrenergic receptor. Eur. J. Biochem. 230: 350-8 [PMID:7601122]

369. Popp BD, Hutchinson DS, Evans BA and Summers RJ. (2004) Stereoselectivity for interactions of agonists and antagonists at mouse, rat and human beta3-adrenoceptors. Eur. J. Pharmacol. 484: 323-31 [PMID:14744619]

370. Potter DE. (1981) Adrenergic pharmacology of aqueous humor dynamics.Pharmacol. Rev. 33: 133-53 [PMID:7323134]

371. Price DT, Lefkowitz RJ, Caron MG, Berkowitz D and Schwinn DA. (1994) Localization of mRNA for three distinct alpha 1-adrenergic receptor subtypes in human tissues: implications for human alpha-adrenergic physiology. Mol. Pharmacol. 45: 171-5 [PMID:8114668] 
372. Procopiou PA, Barrett VJ, Bevan NJ, Biggadike K, Box PC, Butchers PR, Coe DM, Conroy R, Emmons A and Ford AJ et al.. (2010) Synthesis and structure-activity relationships of long-acting beta2 adrenergic receptor agonists incorporating metabolic inactivation: an antedrug approach. J. Med. Chem. 53: 4522-30 [PMID:20462258]

373. Putzke C, Wemhöner K, Sachse FB, Rinné S, Schlichthörl G, Li XT, Jaé L, Eckhardt I, Wischmeyer E and Wulf $\mathrm{H}$ et al.. (2007) The acid-sensitive potassium channel TASK-1 in rat cardiac muscle.Cardiovasc. Res. 75: 59-68 [PMID:17389142]

374. Pönicke K, Heinroth-Hoffmann I and Brodde OE. (2003) Role of beta 1- and beta 2-adrenoceptors in hypertrophic and apoptotic effects of noradrenaline and adrenaline in adult rat ventricular cardiomyocytes. Naunyn Schmiedebergs Arch. Pharmacol. 367: 592-9 [PMID:12750877]

375. Queiróz DB, Mendes FR, Porto CS and Avellar MC. (2002) Alpha1-adrenoceptor subtypes in rat epididymis and the effects of sexual maturation. Biol. Reprod. 66: 508-15 [PMID:11804969]

376. Quinton L, Girard E, Maiga A, Rekik M, Lluel P, Masuyer G, Larregola M, Marquer C, Ciolek J and Magnin T et al.. (2010) Isolation and pharmacological characterization of AdTx1, a natural peptide displaying specific insurmountable antagonism of the alpha1A-adrenoceptor. Br. J. Pharmacol. 159: 316-25 [PMID:20015090]

377. Ragnarsson L, Wang $\mathrm{Cl}$, Andersson $\AA$, Fajarningsih D, Monks T, Brust A, Rosengren KJ and Lewis RJ. (2013) Conopeptide $\rho$-TIA defines a new allosteric site on the extracellular surface of the $\alpha 1 \mathrm{~B}$ adrenoceptor. J. Biol. Chem. 288: 1814-27 [PMID:23184947]

378. Ramarao CS, Denker JM, Perez DM, Gaivin RJ, Riek RP and Graham RM. (1992) Genomic organization and expression of the human alpha 1B-adrenergic receptor. J. Biol. Chem. 267: 21936-45 [PMID:1328250]

379. Ramis JM, González-Sánchez JL, Proenza AM, Martínez-Larrad MT, Fernández-Pérez C, Palou A and Serrano-Ríos M. (2004) The Arg64 allele of the beta 3-adrenoceptor gene but not the -3826G allele of the uncoupling protein 1 gene is associated with increased leptin levels in the Spanish population. Metab. Clin. Exp. 53: 1411-6 [PMID:15536594]

380. Ramsay D, Carr IC, Pediani J, Lopez-Gimenez JF, Thurlow R, Fidock M and Milligan G. (2004) Highaffinity interactions between human alpha1 A-adrenoceptor $\mathrm{C}$-terminal splice variants produce homo- and heterodimers but do not generate the alpha1L-adrenoceptor. Mol. Pharmacol. 66: 228-39 [PMID:15266013]

381. Ranade K, Jorgenson E, Sheu WH, Pei D, Hsiung CA, Chiang FT, Chen YD, Pratt R, Olshen RA and Curb D et al.. (2002) A polymorphism in the beta1 adrenergic receptor is associated with resting heart rate $A m$. J. Hum. Genet. 70: 935-42 [PMID:11854867]

382. Rasmussen SG, Choi HJ, Fung JJ, Pardon E, Casarosa P, Chae PS, Devree BT, Rosenbaum DM, Thian FS and Kobilka TS et al.. (2011) Structure of a nanobody-stabilized active state of the $\beta(2)$ adrenoceptor. Nature 469: 175-80 [PMID:21228869]

383. Rasmussen SG, Choi HJ, Rosenbaum DM, Kobilka TS, Thian FS, Edwards PC, Burghammer M, Ratnala VR, Sanishvili R and Fischetti RF et al.. (2007) Crystal structure of the human beta2 adrenergic G-proteincoupled receptor. Nature 450: 383-7 [PMID:17952055]

384. Rasmussen SG, DeVree BT, Zou Y, Kruse AC, Chung KY, Kobilka TS, Thian FS, Chae PS, Pardon E and Calinski $D$ et al.. (2011) Crystal structure of the $\beta 2$ adrenergic receptor-Gs protein complex.Nature 477: 549-55 [PMID:21772288]

385. Regan JW, Kobilka TS, Yang-Feng TL, Caron MG, Lefkowitz RJ and Kobilka BK. (1988) Cloning and expression of a human kidney cDNA for an alpha 2-adrenergic receptor subtype. Proc. Natl. Acad. Sci. U.S.A. 85: 6301-5 [PMID:2842764]

386. Rivard K, Trépanier-Boulay V, Rindt $\mathrm{H}$ and Fiset C. (2009) Electrical remodeling in a transgenic mouse model of alpha1B-adrenergic receptor overexpression. Am. J. Physiol. Heart Circ. Physiol. 296: H704-18 [PMID:19112097]

387. Rodríguez-Pérez CE, Calvo-Ochoa E, Kalashnikova EV, Reyes-Cruz G, Romero-Avila MT and GarcíaSáinz JA. (2009) Receptor tyrosine kinases regulate alpha1D-adrenoceptor signaling properties: phosphorylation and desensitization. Int. J. Biochem. Cell Biol. 41: 1276-83 [PMID:19038360] 
388. Rohrer DK, Chruscinski A, Schauble EH, Bernstein D and Kobilka BK. (1999) Cardiovascular and metabolic alterations in mice lacking both beta1- and beta2-adrenergic receptors. J. Biol. Chem. 274: 16701-8 [PMID:10358009]

389. Rohrer DK, Desai KH, Jasper JR, Stevens ME, Regula Jr DP, Barsh GS, Bernstein D and Kobilka BK. (1996) Targeted disruption of the mouse beta1-adrenergic receptor gene: developmental and cardiovascular effects. Proc. Natl. Acad. Sci. U.S.A. 93: 7375-80 [PMID:8693001]

390. Rohrer DK, Schauble EH, Desai KH, Kobilka BK and Bernstein D. (1998) Alterations in dynamic heart rate control in the beta 1-adrenergic receptor knockout mouse. Am. J. Physiol. 274: H1184-93 [PMID:9575921]

391. Rokosh DG and Simpson PC. (2002) Knockout of the alpha 1A/C-adrenergic receptor subtype: the alpha $1 \mathrm{~A} / \mathrm{C}$ is expressed in resistance arteries and is required to maintain arterial blood pressure. Proc. Natl. Acad. Sci. U.S.A. 99: 9474-9 [PMID:12093905]

392. Rorabaugh BR, Ross SA, Gaivin RJ, Papay RS, McCune DF, Simpson PC and Perez DM. (2005) alpha1A- but not alpha1B-adrenergic receptors precondition the ischemic heart by a staurosporinesensitive, chelerythrine-insensitive mechanism. Cardiovasc. Res. 65: 436-45 [PMID:15639483]

393. Rosenbaum DM, Zhang C, Lyons JA, Holl R, Aragao D, Arlow DH, Rasmussen SG, Choi HJ, Devree BT and Sunahara RK et al.. (2011) Structure and function of an irreversible agonist- $\beta(2)$ adrenoceptor complex. Nature 469: 236-40 [PMID:21228876]

394. Rosengren AH, Jokubka R, Tojjar D, Granhall C, Hansson O, Li DQ, Nagaraj V, Reinbothe TM, Tuncel J and Eliasson $L$ et al.. (2010) Overexpression of alpha2A-adrenergic receptors contributes to type 2 diabetes. Science 327: 217-20 [PMID:19965390]

395. Ross SA, Rorabaugh BR, Chalothorn D, Yun J, Gonzalez-Cabrera PJ, McCune DF, Piascik MT and Perez DM. (2003) The alpha(1B)-adrenergic receptor decreases the inotropic response in the mouse Langendorff heart model. Cardiovasc. Res. 60: 598-607 [PMID:14659805]

396. Rouget C, Bardou M, Breuiller-Fouché M, Loustalot C, Qi H, Naline E, Croci T, Cabrol D, Advenier C and Leroy MJ. (2005) Beta3-adrenoceptor is the predominant beta-adrenoceptor subtype in human myometrium and its expression is up-regulated in pregnancy. J. Clin. Endocrinol. Metab. 90: 1644-50 [PMID:15585565]

397. Rudner XL, Berkowitz DE, Booth JV, Funk BL, Cozart KL, D'Amico EB, El-Moalem H, Page SO, Richardson CD and Winters $B$ et al.. (1999) Subtype specific regulation of human vascular alpha(1)adrenergic receptors by vessel bed and age. Circulation 100: 2336-43 [PMID:10587338]

398. Ruuskanen JO, Xhaard H, Marjamäki A, Salaneck E, Salminen T, Yan YL, Postlethwait JH, Johnson MS, Larhammar D and Scheinin M. (2004) Identification of duplicated fourth alpha2-adrenergic receptor subtype by cloning and mapping of five receptor genes in zebrafish. Mol. Biol. Evol. 21: 14-28 [PMID:12949138]

399. Sabio M, Jones K and Topiol S. (2008) Use of the X-ray structure of the beta2-adrenergic receptor for drug discovery. Part 2: Identification of active compounds. Bioorg. Med. Chem. Lett. 18: 5391-5 [PMID:18829308]

400. Sadalge A, Coughlin L, Fu H, Wang B, Valladares O, Valentino R and Blendy JA. (2003) alpha 1d Adrenoceptor signaling is required for stimulus induced locomotor activity. Mol. Psychiatry 8: 664-72 [PMID:12874602]

401. Saeed AE, Parmentier JH and Malik KU. (2004) Activation of alpha1A-adrenergic receptor promotes differentiation of rat-1 fibroblasts to a smooth muscle-like phenotype. BMC Cell Biol. 5: 47 [PMID:15603588]

402. Sallinen J, Höglund I, Engström M, Lehtimäki J, Virtanen R, Sirviö J, Wurster S, Savola JM and Haapalinna A. (2007) Pharmacological characterization and CNS effects of a novel highly selective alpha2C-adrenoceptor antagonist JP-1302. Br. J. Pharmacol. 150: 391-402 [PMID:17220913]

403. Salomonsson M, Oker M, Kim S, Zhang H, Faber JE and Arendshorst WJ. (2001) Alpha1-adrenoceptor subtypes on rat afferent arterioles assessed by radioligand binding and RT-PCR. Am. J. Physiol. Renal Physiol. 281: F172-8 [PMID:11399658]

404. Santana N, Mengod G and Artigas F. (2013) Expression of $\alpha(1)$-adrenergic receptors in rat prefrontal 
cortex: cellular co-localization with 5-HT(2A) receptors. Int. J. Neuropsychopharmacol. 16: 1139-51 [PMID:23195622]

405. Sarsero D, Molenaar $P$ and Kaumann AJ. (1998) Validity of (-)-[3H]-CGP 12177A as a radioligand for the 'putative beta4-adrenoceptor' in rat atrium. Br. J. Pharmacol. 123: 371-80 [PMID:9504376]

406. Sato M, Horinouchi T, Hutchinson DS, Evans BA and Summers RJ. (2007) Ligand-directed signaling at the beta3-adrenoceptor produced by 3-(2-Ethylphenoxy)-1-[(1,S)-1,2,3,4-tetrahydronapth-1-ylamino]-2S-2propanol oxalate (SR59230A) relative to receptor agonists. Mol. Pharmacol. 72: 1359-68 [PMID:17717109]

407. Sato M, Hutchinson DS, Evans BA and Summers RJ. (2008) The beta3-adrenoceptor agonist 4[[(Hexylamino)carbonyl]amino]-N-[4-[2-[[(2S)-2-hydroxy-3-(4-hydroxyphenoxy)propyl]amino]ethyl]-phenyl]benzenesulfonamide (L755507) and antagonist (S)-N-[4-[2-[[3-[3-(acetamidomethyl)phenoxy]-2hydroxypropyl]amino]-ethyl]phenyl]benzenesulfonamide (L748337) activate different signaling pathways in Chinese hamster ovary-K1 cells stably expressing the human beta3-adrenoceptor. Mol. Pharmacol. 74: 1417-28 [PMID:18684840]

408. Sato M, Hutchinson DS, Halls ML, Furness SG, Bengtsson T, Evans BA and Summers RJ. (2012) Interaction with caveolin-1 modulates G protein coupling of mouse $\beta 3$-adrenoceptor. J. Biol. Chem. 287: 20674-88 [PMID:22535965]

409. Sato $Y$, Kurose H, Isogaya M and Nagao T. (1996) Molecular characterization of pharmacological properties of T-0509 for beta-adrenoceptors. Eur. J. Pharmacol. 315: 363-7 [PMID:8982677]

410. Saussy Jr DL, Goetz AS, Queen KL, King HK, Lutz MW and Rimele TJ. (1996) Structure activity relationships of a series of buspirone analogs at alpha-1 adrenoceptors: further evidence that rat aorta alpha-1 adrenoceptors are of the alpha-1D-subtype. J. Pharmacol. Exp. Ther. 278: 136-44 [PMID:8764344]

411. Schilit S and Benzeroual KE. (2009) Silodosin: a selective alpha1A-adrenergic receptor antagonist for the treatment of benign prostatic hyperplasia. Clin Ther 31: 2489-502 [PMID:20109995]

412. Schotte A, Janssen PF, Gommeren W, Luyten WH, Van Gompel P, Lesage AS, De Loore K and Leysen JE. (1996) Risperidone compared with new and reference antipsychotic drugs: in vitro and in vivo receptor binding. Psychopharmacology (Berl.) 124: 57-73 [PMID:8935801]

413. Schwinn DA, Johnston GI, Page SO, Mosley MJ, Wilson KH, Worman NP, Campbell S, Fidock MD, Furness LM and Parry-Smith DJ et al.. (1995) Cloning and pharmacological characterization of human alpha-1 adrenergic receptors: sequence corrections and direct comparison with other species homologues. J. Pharmacol. Exp. Ther. 272: 134-42 [PMID:7815325]

414. Schwinn DA, Lomasney JW, Lorenz W, Szklut PJ, Fremeau Jr RT, Yang-Feng TL, Caron MG, Lefkowitz RJ and Cotecchia S. (1990) Molecular cloning and expression of the cDNA for a novel alpha 1-adrenergic receptor subtype. J. Biol. Chem. 265: 8183-9 [PMID:1970822]

415. Schwinn DA and Michelotti GA. (2000) alpha1-adrenergic receptors in the lower urinary tract and vascular bed: potential role for the alpha1d subtype in filling symptoms and effects of ageing on vascular expression. BJU Int. 85 Suppl 2: 6-11 [PMID:10781179]

416. Segura V, Flacco N, Oliver E, Barettino D, D'Ocon P and Ivorra MD. (2010) Alpha1-adrenoceptors in the rat cerebral cortex: new insights into the characterization of alpha1L-and alpha1D-adrenoceptors. Eur. J. Pharmacol. 641: 41-8 [PMID:20511116]

417. Seifert R, Lee TW, Lam VT and Kobilka BK. (1998) Reconstitution of beta2-adrenoceptor-GTP-bindingprotein interaction in Sf9 cells--high coupling efficiency in a beta2-adrenoceptor-G(s alpha) fusion protein. Eur. J. Biochem. 255: 369-82 [PMID:9716378]

418. Semmler J, Gebert U, Eisenhut T, Moeller J, Schönharting MM, Alléra A and Endres S. (1993) Xanthine derivatives: comparison between suppression of tumour necrosis factor-alpha production and inhibition of cAMP phosphodiesterase activity. Immunology 78: 520-5 [PMID:8388363]

419. Seo B, Choy EW, Maudsley S, Miller WE, Wilson BA and Luttrell LM. (2000) Pasteurella multocida toxin stimulates mitogen-activated protein kinase via $\mathrm{G}(\mathrm{q} / 11)$-dependent transactivation of the epidermal growth factor receptor. J. Biol. Chem. 275: 2239-45 [PMID:10636931]

420. Severi C, Tattoli I, Romano G, Corleto VD and Delle Fave G. (2004) Beta3-adrenoceptors: relaxant 
function and mRNA detection in smooth muscle cells isolated from the human colon. Can. J. Physiol. Pharmacol. 82: 515-22 [PMID:15389299]

421. Sharif NA, Xu SX, Crider JY, McLaughlin M and Davis TL. (2001) Levobetaxolol (Betaxon) and other betaadrenergic antagonists: preclinical pharmacology, IOP-lowering activity and sites of action in human eyes. J Ocul Pharmacol Ther 17: 305-17 [PMID:11572462]

422. Sharpe IA, Thomas L, Loughnan M, Motin L, Palant E, Croker DE, Alewood D, Chen S, Graham RM and Alewood PF et al.. (2003) Allosteric alpha 1-adrenoreceptor antagonism by the conopeptide rho-TIAJ. Biol. Chem. 278: $34451-7$ [PMID:12824165]

423. Shi T, Duan ZH, Papay R, Pluskota E, Gaivin RJ, de la Motte CA, Plow EF and Perez DM. (2006) Novel alpha1-adrenergic receptor signaling pathways: secreted factors and interactions with the extracellular matrix. Mol. Pharmacol. 70: 129-42 [PMID:16617165]

424. Shi T, Gaivin RJ, McCune DF, Gupta M and Perez DM. (2007) Dominance of the alpha1B-adrenergic receptor and its subcellular localization in human and TRAMP prostate cancer cell lines. J. Recept. Signal Transduct. Res. 27: 27-45 [PMID:17365508]

425. Shi T, Moravec CS and Perez DM. (2013) Novel proteins associated with human dilated cardiomyopathy: selective reduction in $\alpha 1 \mathrm{~A}$-adrenergic receptors and increased desensitization proteins. J. Recept. Signal Transduct. Res. 33: 96-106 [PMID:23384050]

426. Shi T, Papay RS and Perez DM. (2012) $\propto(1 \mathrm{~A})$-adrenergic receptor differentially regulates STAT3 phosphorylation through PKC€ and PKC $\delta$ in myocytes. J. Recept. Signal Transduct. Res. 32: 76-86 [PMID:22268811]

427. Shibata K, Foglar R, Horie K, Obika K, Sakamoto A, Ogawa S and Tsujimoto G. (1995) KMD-3213, a novel, potent, alpha 1a-adrenoceptor-selective antagonist: characterization using recombinant human alpha 1-adrenoceptors and native tissues. Mol. Pharmacol. 48: 250-8 [PMID:7651358]

428. Shihara N, Yasuda K, Moritani T, Ue H, Adachi T, Tanaka H, Tsuda K and Seino Y. (1999) The association between Trp64Arg polymorphism of the beta3-adrenergic receptor and autonomic nervous system activity. J. Clin. Endocrinol. Metab. 84: 1623-7 [PMID:10323390]

429. Sigala S, Peroni A, Mirabella G, Fornari S, Palazzolo F, Pezzotti G, Simeone C, Cunico SC and Spano P. (2004) Alpha1 adrenoceptor subtypes in human urinary bladder: sex and regional comparison. Life Sci. 76: 417-27 [PMID:15530504]

430. Simonneaux V, Ebadi M and Bylund DB. (1991) Identification and characterization of alpha 2D-adrenergic receptors in bovine pineal gland. Mol. Pharmacol. 40: 235-41 [PMID:1652052]

431. Skeberdis VA, Jurevicius J and Fischmeister R. (1999) b3-adrenergic regulation of cardiac L-type Ca2+ current in human atrial myocytes. Biophys J. 76: A343-A343

432. Small KM, Schwarb MR, Glinka C, Theiss CT, Brown KM, Seman CA and Liggett SB. (2006) Alpha2Aand alpha2C-adrenergic receptors form homo- and heterodimers: the heterodimeric state impairs agonistpromoted GRK phosphorylation and beta-arrestin recruitment. Biochemistry 45: 4760-7 [PMID:16605244]

433. Snabaitis AK, Yokoyama $H$ and Avkiran M. (2000) Roles of mitogen-activated protein kinases and protein kinase $\mathrm{C}$ in alpha(1A)-adrenoceptor-mediated stimulation of the sarcolemmal $\mathrm{Na}(+)-\mathrm{H}(+)$ exchanger. Circ. Res. 86: 214-20 [PMID:10666418]

434. Snitker S, Odeleye OE, Hellmer J, Boschmann M, Monroe MB, Shuldiner AR and Ravussin E. (1997) No effect of the Trp64Arg beta 3-adrenoceptor variant on in vivo lipolysis in subcutaneous adipose tissue. Diabetologia 40: 838-842 [PMID:9243106]

435. Soriano-Ursúa MA, McNaught-Flores DA, Nieto-Alamilla G, Segura-Cabrera A, Correa-Basurto J, AriasMontaño JA and Trujillo-Ferrara JG. (2012) Cell-based and in-silico studies on the high intrinsic activity of two boron-containing salbutamol derivatives at the human $\beta_{2}$-adrenoceptor. Bioorg. Med. Chem. 20: 93341 [PMID:22182578]

436. Soriano-Ursúa MA, Valencia-Hernández I, Arellano-Mendoza MG, Correa-Basurto J and Trujillo-Ferrara JG. (2009) Synthesis, pharmacological and in silico evaluation of 1-(4-di-hydroxy-3,5-dioxa-4borabicyclo[4.4.0]deca-7,9,11-trien-9-yl)-2-(tert-butylamino)ethanol, a compound designed to act as a beta2 adrenoceptor agonist. Eur J Med Chem 44: 2840-6 [PMID:19168263] 
437. Spiegl G, Zupkó I, Minorics R, Csík G, Csonka D and Falkay G. (2009) Effects of experimentally induced diabetes mellitus on pharmacologically and electrically elicited myometrial contractility. Clin. Exp. Pharmacol. Physiol. 36: 884-91 [PMID:19298542]

438. Stam WB, Van der Graaf PH and Saxena PR. (1998) Functional characterisation of the pharmacological profile of the putative alpha1B-adrenoceptor antagonist, (+)-cyclazosin. Eur. J. Pharmacol. 361: 79-83 [PMID:9851544]

439. Stiles GL, Caron MG and Lefkowitz RJ. (1984) Beta-adrenergic receptors: biochemical mechanisms of physiological regulation. Physiol. Rev. 64: 661-743 [PMID:6143332]

440. Strosberg AD. (1997) Structure and function of the beta 3-adrenergic receptor.Annu. Rev. Pharmacol. Toxicol. 37: 421-50 [PMID:9131260]

441. Strosberg AD, Gerhardt C, Gros J, Jockers R and Piétri-Rouxel F. (1998) On the putative existence of a fourth $\alpha$-adrenoceptor: Proof is still missing. Trends Pharmacol. Sci. 19: 165-166

442. Summers RJ. (2008) Atypical pharmacologies at beta-adrenoceptors.Br. J. Pharmacol. 155: 285-7 [PMID:18641673]

443. Susulic VS, Frederich RC, Lawitts J, Tozzo E, Kahn BB, Harper ME, Himms-Hagen J, Flier JS and Lowell BB. (1995) Targeted disruption of the beta 3-adrenergic receptor gene. J. Biol. Chem. 270: 29483-92 [PMID:7493988]

444. Suzuki T, Nantel F, Bonin H, Valiquette M and Bouvier M. (1993) Cellular characterization of the pharmacological selectivity and tachyphylactic properties of denopamine for the human beta adrenergic receptors. J. Pharmacol. Exp. Ther. 267: 785-90 [PMID:7902433]

445. Swaminath G, Lee TW and Kobilka B. (2003) Identification of an allosteric binding site for Zn2+ on the beta2 adrenergic receptor. J. Biol. Chem. 278: 352-6 [PMID:12409304]

446. Swaminath G, Steenhuis J, Kobilka B and Lee TW. (2002) Allosteric modulation of beta2-adrenergic receptor by Zn(2+). Mol. Pharmacol. 61: 65-72 [PMID:11752207]

447. Szot P, White SS, Greenup JL, Leverenz JB, Peskind ER and Raskind MA. (2005) Alpha1-adrenoreceptor in human hippocampus: binding and receptor subtype mRNA expression. Brain Res. Mol. Brain Res. 139: 367-71 [PMID:16039007]

448. Szot P, White SS, Greenup JL, Leverenz JB, Peskind ER and Raskind MA. (2007) Changes in adrenoreceptors in the prefrontal cortex of subjects with dementia: evidence of compensatory changes. Neuroscience 146: 471-80 [PMID:17324522]

449. Szot P, White SS, Greenup JL, Leverenz JB, Peskind ER and Raskind MA. (2006) Compensatory changes in the noradrenergic nervous system in the locus ceruleus and hippocampus of postmortem subjects with Alzheimer's disease and dementia with Lewy bodies. J. Neurosci. 26: 467-78 [PMID:16407544]

450. Takahashi K, Hossain M, Ahmed M, Bhuiyan MA, Ohnuki T and Nagatomo T. (2007) Asp125 and Thr130 in transmembrane domain 3 are major sites of alpha1b-adrenergic receptor antagonist binding. Biol. Pharm. Bull. 30: 1891-4 [PMID:17917257]

451. Takakura K, Taniguchi T, Muramatsu I, Takeuchi K and Fukuda S. (2002) Modification of alpha1 adrenoceptors by peroxynitrite as a possible mechanism of systemic hypotension in sepsis. Crit. Care Med. 30: 894-9 [PMID:11940765]

452. Takasu T, Ukai M, Sato S, Matsui T, Nagase I, Maruyama T, Sasamata M, Miyata K, Uchida $H$ and Yamaguchi O. (2007) Effect of (R)-2-(2-aminothiazol-4-yl)-4'-\{2-[(2-hydroxy-2-phenylethyl)amino]ethyl\} acetanilide (YM178), a novel selective beta3-adrenoceptor agonist, on bladder function. J. Pharmacol. Exp. Ther. 321: 642-7 [PMID:17293563]

453. Tan M, Walwyn WM, Evans CJ and Xie CW. (2009) p38 MAPK and beta-arrestin 2 mediate functional interactions between endogenous micro-opioid and alpha2A-adrenergic receptors in neurons. J. Biol. Chem. 284: 6270-81 [PMID:19126537]

454. Taniguchi N, Hamada K, Ogasawara T, Ukai Y, Yoshikuni Y and Kimura K. (1996) NS-49, an alpha 1Aadrenoceptor agonist, selectively increases intraurethral pressure in dogs. Eur. J. Pharmacol. 318: 117-22 [PMID:9007522] 
455. Taniguchi T, Inagaki R, Murata S, Akiba I and Muramatsu I. (1999) Microphysiometric analysis of human alpha1a-adrenoceptor expressed in Chinese hamster ovary cells. Br. J. Pharmacol. 127: 962-8 [PMID:10433504]

456. Tanoue A, Koba M, Miyawaki S, Koshimizu TA, Hosoda C, Oshikawa S and Tsujimoto G. (2002) Role of the alpha1D-adrenergic receptor in the development of salt-induced hypertension. Hypertension 40: 101-6 [PMID:12105146]

457. Tanoue A, Nasa Y, Koshimizu T, Shinoura H, Oshikawa S, Kawai T, Sunada S, Takeo S and Tsujimoto G. (2002) The alpha(1D)-adrenergic receptor directly regulates arterial blood pressure via vasoconstriction. $J$. Clin. Invest. 109: 765-75 [PMID:11901185]

458. Tate KM, Briend-Sutren MM, Emorine LJ, Delavier-Klutchko C, Marullo S and Strosberg AD. (1991) Expression of three human beta-adrenergic-receptor subtypes in transfected Chinese hamster ovary cells. Eur. J. Biochem. 196: 357-61 [PMID:1848818]

459. Tavernier G, Barbe P, Galitzky J, Berlan M, Caput D, Lafontan M and Langin D. (1996) Expression of beta3-adrenoceptors with low lipolytic action in human subcutaneous white adipocytes. J. Lipid Res. 37: 87-97 [PMID:8820105]

460. Tavernier G, Toumaniantz G, Erfanian M, Heymann MF, Laurent K, Langin D and Gauthier C. (2003) beta3-Adrenergic stimulation produces a decrease of cardiac contractility ex vivo in mice overexpressing the human beta3-adrenergic receptor. Cardiovasc. Res. 59: 288-96 [PMID:12909312]

461. Tayebati SK, Bronzetti E, Morra Di Cella S, Mulatero P, Ricci A, Rossodivita I, Schena M, Schiavone D, Veglio F and Amenta F. (2000) In situ hybridization and immunocytochemistry of alpha1-adrenoceptors in human peripheral blood lymphocytes. J Auton Pharmacol 20: 305-12 [PMID:11350496]

462. Testa R, Guarneri L, Angelico P, Poggesi E, Taddei C, Sironi G, Colombo D, Sulpizio AC, Naselsky DP and Hieble JP et al.. (1997) Pharmacological characterization of the uroselective alpha-1 antagonist Rec 15/2739 (SB 216469): role of the alpha-1L adrenoceptor in tissue selectivity, part II. J. Pharmacol. Exp. Ther. 281: 1284-93 [PMID:9190864]

463. Tonolo G, Melis MG, Secchi G, Atzeni MM, Angius MF, Carboni A, Ciccarese M, Malavasi A and Maioli M. (1999) Association of Trp64Arg beta 3-adrenergic-receptor gene polymorphism with essential hypertension in the Sardinian population. J. Hypertens. 17: 33-8 [PMID:10100091]

464. Townsend SA, Jung AS, Hoe YS, Lefkowitz RY, Khan SA, Lemmon CA, Harrison RW, Lee K, Barouch LA and Cotecchia $S$ et al.. (2004) Critical role for the alpha-1B adrenergic receptor at the sympathetic neuroeffector junction. Hypertension 44: 776-82 [PMID:15466664]

465. Trochu JN, Leblais V, Rautureau Y, Bévérelli F, Le Marec H, Berdeaux A and Gauthier C. (1999) Beta 3adrenoceptor stimulation induces vasorelaxation mediated essentially by endothelium-derived nitric oxide in rat thoracic aorta. Br. J. Pharmacol. 128: 69-76 [PMID:10498836]

466. Tsuchihashi H, Nakashima Y, Kinami J and Nagatomo T. (1990) Characteristics of 125l-iodocyanopindolol binding to beta-adrenergic and serotonin-1B receptors of rat brain: selectivity of beta-adrenergic agents. Jpn. J. Pharmacol. 52: 195-200 [PMID:1968985]

467. Turki J, Lorenz JN, Green SA, Donnelly ET, Jacinto M and Liggett SB. (1996) Myocardial signaling defects and impaired cardiac function of a human beta 2-adrenergic receptor polymorphism expressed in transgenic mice. Proc. Natl. Acad. Sci. U.S.A. 93: 10483-8 [PMID:8816827]

468. Turki J, Pak J, Green SA, Martin RJ and Liggett SB. (1995) Genetic polymorphisms of the beta 2adrenergic receptor in nocturnal and nonnocturnal asthma. Evidence that Gly 16 correlates with the nocturnal phenotype. J. Clin. Invest. 95: 1635-41 [PMID:7706471]

469. Uberti MA, Hague C, Oller H, Minneman KP and Hall RA. (2005) Heterodimerization with beta2-adrenergic receptors promotes surface expression and functional activity of alpha1D-adrenergic receptors. J. Pharmacol. Exp. Ther. 313: 16-23 [PMID:15615865]

470. Uberti MA, Hall RA and Minneman KP. (2003) Subtype-specific dimerization of alpha 1-adrenoceptors: effects on receptor expression and pharmacological properties. Mol. Pharmacol. 64: 1379-90 [PMID:14645668]

471. Uehling DE, Shearer BG, Donaldson KH, Chao EY, Deaton DN, Adkison KK, Brown KK, Cariello NF, 
Faison WL and Lancaster ME et al.. (2006) Biarylaniline phenethanolamines as potent and selective beta3 adrenergic receptor agonists. J. Med. Chem. 49: 2758-71 [PMID:16640337]

472. Uhlén S, Porter AC and Neubig RR. (1994) The novel alpha-2 adrenergic radioligand [3H]-MK912 is alpha-2C selective among human alpha-2A, alpha-2B and alpha-2C adrenoceptors. J. Pharmacol. Exp. Ther. 271: 1558-65 [PMID:7996470]

473. Umekawa T, Yoshida T, Sakane N, Kogure A, Kondo M and Honjyo H. (1999) Trp64Arg mutation of beta3-adrenoceptor gene deteriorates lipolysis induced by beta3-adrenoceptor agonist in human omental adipocytes. Diabetes 48: 117-20 [PMID:9892231]

474. van Wieringen JP, Michel-Reher MB, Hatanaka T, Ueshima K and Michel MC. (2013) The new radioligand $[(3) \mathrm{H}]-\mathrm{L}$ 748,337 differentially labels human and rat $\beta 3$-adrenoceptors. Eur. J. Pharmacol. 720: 124-30 [PMID:24183974]

475. Varghese P, Harrison RW, Lofthouse RA, Georgakopoulos D, Berkowitz DE and Hare JM. (2000) beta(3)adrenoceptor deficiency blocks nitric oxide-dependent inhibition of myocardial contractility. J. Clin. Invest. 106: 697-703 [PMID:10974023]

476. Vilardaga JP, Nikolaev VO, Lorenz K, Ferrandon S, Zhuang Z and Lohse MJ. (2008) Conformational cross-talk between alpha2A-adrenergic and mu-opioid receptors controls cell signaling. Nat. Chem. Biol. 4: 126-31 [PMID:18193048]

477. Villégier AS, Drouin C, Bizot JC, Marien M, Glowinski J, Colpaërt F and Tassin JP. (2003) Stimulation of postsynaptic alpha1b- and alpha2-adrenergic receptors amplifies dopamine-mediated locomotor activity in both rats and mice. Synapse 50: 277-84 [PMID:14556232]

478. Vinci MC, Bellik L, Filippi S, Ledda F and Parenti A. (2007) Trophic effects induced by alpha1Dadrenoceptors on endothelial cells are potentiated by hypoxia. Am. J. Physiol. Heart Circ. Physiol.293: H2140-7 [PMID:17660397]

479. Wacker D, Fenalti G, Brown MA, Katritch V, Abagyan R, Cherezov V and Stevens RC. (2010) Conserved binding mode of human beta2 adrenergic receptor inverse agonists and antagonist revealed by X-ray crystallography. J. Am. Chem. Soc. 132: 11443-5 [PMID:20669948]

480. Walden PD, Gerardi $C$ and Lepor H. (1999) Localization and expression of the alpha1A-1, alpha1B and alpha1D-adrenoceptors in hyperplastic and non-hyperplastic human prostate. J. Urol. 161: 635-40 [PMID:9915474]

481. Walston J, Silver K, Bogardus C, Knowler WC, Celi FS, Austin S, Manning B, Strosberg AD, Stern MP, Raben $\mathrm{N}$ and et al.. (1995) Time of onset of non-insulin-dependent diabetes mellitus and genetic variation in the beta 3-adrenergic-receptor gene. N Engl J Med. 333: 343-347 [PMID:7609750]

482. Wang SY, Song Y, Xu M, He QH, Han QD and Zhang YY. (2007) Internalization and distribution of three alpha1-adrenoceptor subtypes in HEK293A cells before and after agonist stimulation. Acta Pharmacol. Sin. 28: 359-66 [PMID:17302998]

483. Warne T, Moukhametzianov R, Baker JG, Nehmé R, Edwards PC, Leslie AG, Schertler GF and Tate CG. (2011) The structural basis for agonist and partial agonist action on a $\beta(1)$-adrenergic receptor. Nature 469 : 241-4 [PMID:21228877]

484. Warne T, Serrano-Vega MJ, Baker JG, Moukhametzianov R, Edwards PC, Henderson R, Leslie AG, Tate CG and Schertler GF. (2008) Structure of a beta1-adrenergic G-protein-coupled receptor. Nature 454: 48691 [PMID:18594507]

485. Waugh DJ, Gaivin RJ, Damron DS, Murray PA and Perez DM. (1999) Binding, partial agonism, and potentiation of alpha(1)-adrenergic receptor function by benzodiazepines: A potential site of allosteric modulation. J. Pharmacol. Exp. Ther. 291: 1164-71 [PMID:10565838]

486. Waugh DJ, Gaivin RJ, Zuscik MJ, Gonzalez-Cabrera P, Ross SA, Yun J and Perez DM. (2001) Phe-308 and Phe-312 in transmembrane domain 7 are major sites of alpha 1-adrenergic receptor antagonist binding. Imidazoline agonists bind like antagonists. J. Biol. Chem. 276: 25366-71 [PMID:11331292]

487. Weber AE, Ok HO, Alvaro RF, Candelore MR, Cascieri MA, Chiu SH, Deng L, Forrest MJ, Hom GJ and Hutchins JE et al.. (1998) 3-Pyridyloxypropanolamine agonists of the beta 3 adrenergic receptor with improved pharmacokinetic properties. Bioorg. Med. Chem. Lett. 8: 2111-6 [PMID:9873496] 
488. Weinshank RL, Adham N, Macchi M, Olsen MA, Branchek TA and Hartig PR. (1991) Molecular cloning and characterization of a high affinity dopamine receptor (D1 beta) and its pseudogene. J. Biol. Chem. 266: 22427-35 [PMID:1834671]

489. Weinshank RL, Zgombick JM, Macchi M, Adham N, Lichtblau H, Branchek TA and Hartig PR. (1990) Cloning, expression, and pharmacological characterization of a human alpha 2B-adrenergic receptor. Mol. Pharmacol. 38: 681-8 [PMID:2172775]

490. Wenzel-Seifert K, Liu HY and Seifert R. (2002) Similarities and differences in the coupling of human beta1- and beta2-adrenoceptors to Gs(alpha) splice variants. Biochem. Pharmacol. 64: 9-20 [PMID:12106601]

491. Wetzel JM, Miao SW, Forray C, Borden LA, Branchek TA and Gluchowski C. (1995) Discovery of alpha 1a-adrenergic receptor antagonists based on the L-type Ca2+ channel antagonist niguldipine. J. Med. Chem. 38: 1579-81 [PMID:7752182]

492. Williams TJ, Blue DR, Daniels DV, Davis B, Elworthy T, Gever JR, Kava MS, Morgans D, Padilla F and Tassa $S$ et al.. (1999) In vitro alpha1-adrenoceptor pharmacology of Ro 70-0004 and RS-100329, novel alpha1A-adrenoceptor selective antagonists. Br. J. Pharmacol. 127: 252-8 [PMID:10369480]

493. Wilson AL, Seibert K, Brandon S, Cragoe Jr EJ and Limbird LE. (1991) Monovalent cation and amiloride analog modulation of adrenergic ligand binding to the unglycosylated alpha 2B-adrenergic receptor subtype. Mol. Pharmacol. 39: 481-6 [PMID:1850091]

494. Wilson AL, Womble SW, Prakash C, Cragoe Jr EJ, Blair IA and Limbird LE. (1992) Novel amiloride analog allosterically modulates the alpha 2-adrenergic receptor but does not inhibit $\mathrm{Na}+/ \mathrm{H}+$ exchange. $\mathrm{Mol}$. Pharmacol. 42: 175-9 [PMID:1325028]

495. Wright CD, Chen Q, Baye NL, Huang Y, Healy CL, Kasinathan S and O'Connell TD. (2008) Nuclear alpha1-adrenergic receptors signal activated ERK localization to caveolae in adult cardiac myocytes. Circ. Res. 103: 992-1000 [PMID:18802028]

496. Wright CD, Wu SC, Dahl EF, Sazama AJ and O'Connell TD. (2012) Nuclear localization drives $\alpha 1$ adrenergic receptor oligomerization and signaling in cardiac myocytes. Cell. Signal. 24: 794-802 [PMID:22120526]

497. Wrzal PK, Devost D, Pétrin D, Goupil E, lorio-Morin C, Laporte SA, Zingg HH and Hébert TE. (2012) Allosteric interactions between the oxytocin receptor and the $\beta 2$-adrenergic receptor in the modulation of ERK1/2 activation are mediated by heterodimerization. Cell. Signal. 24: 342-50 [PMID:21963428]

498. Wrzal PK, Goupil E, Laporte SA, Hébert TE and Zingg HH. (2012) Functional interactions between the oxytocin receptor and the $\beta 2$-adrenergic receptor: implications for ERK $1 / 2$ activation in human myometrial cells. Cell. Signal. 24: 333-41 [PMID:21964067]

499. Xie HG, Kim RB, Stein CM, Gainer JV, Brown NJ and Wood AJ. (1999) Alpha1A-adrenergic receptor polymorphism: association with ethnicity but not essential hypertension. Pharmacogenetics 9: 651-6 [PMID:10591546]

500. Xu J, He J, Castleberry AM, Balasubramanian S, Lau AG and Hall RA. (2003) Heterodimerization of alpha 2A- and beta 1-adrenergic receptors. J. Biol. Chem. 278: 10770-7 [PMID:12529373]

501. Yan M, Sun J, Bird PI, Liu DL, Grigg M and Lim YL. (2001) Alpha1A- and alpha1B-adrenoceptors are the major subtypes in human saphenous vein. Life Sci. 68: 1191-8 [PMID:11228103]

502. Yanagisawa T, Sato T, Yamada H, Sukegawa J and Nunoki K. (2000) Selectivity and potency of agonists for the three subtypes of cloned human beta-adrenoceptors expressed in Chinese hamster ovary cells.

Tohoku J. Exp. Med. 192: 181-93 [PMID:11249148]

503. Yanase H, Wang X, Momota $Y$, Nimura T and Kawatani M. (2008) The involvement of urothelial alpha1A adrenergic receptor in controlling the micturition reflex. Biomed. Res. 29: 239-44 [PMID:18997438]

504. Yang J, Dolinger M, Ritaccio G, Mazurkiewicz J, Conti D, Zhu X and Huang Y. (2012) Leucine stimulates insulin secretion via down-regulation of surface expression of adrenergic $\alpha 2 \mathrm{~A}$ receptor through the mTOR (mammalian target of rapamycin) pathway: implication in new-onset diabetes in renal transplantation. $J$. Biol. Chem. 287: 24795-806 [PMID:22645144]

505. Yatani A, Tajima Y and Green SA. (1999) Coupling of beta-adrenergic receptors to cardiac L-type Ca2+ 
channels: preferential coupling of the beta1 versus beta2 receptor subtype and evidence for PKAindependent activation of the channel. Cell. Signal. 11: 337-42 [PMID:10376806]

506. Yoshio R, Taniguchi T, Itoh $\mathrm{H}$ and Muramatsu I. (2001) Affinity of serotonin receptor antagonists and agonists to recombinant and native alpha1-adrenoceptor subtypes. Jpn. J. Pharmacol. 86: 189-95 [PMID:11459121]

507. Young $P$, Berge J, Chapman $H$ and Cawthorne MA. (1989) Novel alpha 2-adrenoceptor antagonists show selectivity for alpha 2A- and alpha 2B-adrenoceptor subtypes. Eur. J. Pharmacol. 168: 381-6 [PMID:2573535]

508. Yun J, Gaivin RJ, McCune DF, Boongird A, Papay RS, Ying Z, Gonzalez-Cabrera PJ, Najm I and Perez DM. (2003) Gene expression profile of neurodegeneration induced by alpha1B-adrenergic receptor overactivity: NMDA/GABAA dysregulation and apoptosis. Brain 126: 2667-81 [PMID:12937073]

509. Yun J, Zuscik MJ, Gonzalez-Cabrera P, McCune DF, Ross SA, Gaivin R, Piascik MT and Perez DM. (2003) Gene expression profiling of alpha(1b)-adrenergic receptor-induced cardiac hypertrophy by oligonucleotide arrays. Cardiovasc. Res. 57: 443-55 [PMID:12566117]

510. Zacharia J, Hillier C, Tanoue A, Tsujimoto G, Daly CJ, McGrath JC and MacDonald A. (2005) Evidence for involvement of alpha1D-adrenoceptors in contraction of femoral resistance arteries using knockout mice.

Br. J. Pharmacol. 146: 942-51 [PMID:16170328]

511. Zeng DW, Harrison JK, D'Angelo DD, Barber CM, Tucker AL, Lu ZH and Lynch KR. (1990) Molecular characterization of a rat alpha 2B-adrenergic receptor. Proc. Natl. Acad. Sci. U.S.A. 87: 3102-6 [PMID:2158103]

512. Zhang H, Cotecchia S, Thomas SA, Tanoue A, Tsujimoto G and Faber JE. (2004) Gene deletion of dopamine beta-hydroxylase and alpha1-adrenoceptors demonstrates involvement of catecholamines in vascular remodeling. Am. J. Physiol. Heart Circ. Physiol. 287: H2106-14 [PMID:15231500]

513. Zhang $\mathrm{H}$ and Faber JE. (2001) Trophic effect of norepinephrine on arterial intima-media and adventitia is augmented by injury and mediated by different alpha1-adrenoceptor subtypes. Circ. Res. 89: 815-22 [PMID:11679412]

514. Zhang $Q$ and Tan $Y$. (2011) Nerve growth factor augments neuronal responsiveness to noradrenaline in cultured dorsal root ganglion neurons of rats. Neuroscience 193: 72-9 [PMID:21784134]

515. Zhang Y, Kolli T, Hivley R, Jaber L, Zhao FI, Yan J and Herness S. (2010) Characterization of the expression pattern of adrenergic receptors in rat taste buds. Neuroscience 169: 1421-37 [PMID:20478367]

516. Zhang Y, Wat N, Stratton IM, Warren-Perry MG, Orho M, Groop L and Turner RC. (1996) UKPDS 19: heterogeneity in NIDDM: separate contributions of IRS-1 and beta 3-adrenergic-receptor mutations to insulin resistance and obesity respectively with no evidence for glycogen synthase gene mutations. UK Prospective Diabetes Study. Diabetologia 39: 1505-11 [PMID:8960833]

517. Zhao MM, Hwa J and Perez DM. (1996) Identification of critical extracellular loop residues involved in alpha 1-adrenergic receptor subtype-selective antagonist binding. Mol. Pharmacol. 50: 1118-26 [PMID:8913343]

518. Zhao X, Park J, Ho D, Gao S, Yan L, Ge H, lismaa S, Lin L, Tian B and Vatner DEet al.. (2012) Cardiomyocyte overexpression of the $\alpha 1 \mathrm{~A}$-adrenergic receptor in the rat phenocopies second but not first window preconditioning. Am. J. Physiol. Heart Circ. Physiol.302: H1614-24 [PMID:22307672]

519. Zhou SG, Lu JL and Hui JH. (2011) Comparing efficacy of $\alpha 1 \mathrm{D}$-receptor antagonist naftopidil and $\alpha 1 \mathrm{~A} / \mathrm{D}$ receptor antagonist tamsulosin in management of distal ureteral stones. World J Urol 29: 767-71 [PMID:21845472]

520. Zhu WZ, Chakir K, Zhang S, Yang D, Lavoie C, Bouvier M, Hébert TE, Lakatta EG, Cheng H and Xiao RP. (2005) Heterodimerization of beta1- and beta2-adrenergic receptor subtypes optimizes beta-adrenergic modulation of cardiac contractility. Circ. Res. 97: 244-51 [PMID:16002745]

521. Zilberfarb V, Piétri-Rouxel F, Jockers R, Krief S, Delouis C, Issad T and Strosberg AD. (1997) Human immortalized brown adipocytes express functional beta3-adrenoceptor coupled to lipolysis. J. Cell. Sci. 110 ( Pt 7): 801-7 [PMID:9133667]

522. Zuscik MJ, Chalothorn D, Hellard D, Deighan C, McGee A, Daly CJ, Waugh DJ, Ross SA, Gaivin RJ and 
Morehead AJ et al.. (2001) Hypotension, autonomic failure, and cardiac hypertrophy in transgenic mice overexpressing the alpha 1B-adrenergic receptor. J. Biol. Chem. 276: 13738-43 [PMID:11278430]

523. Zuscik MJ, Sands S, Ross SA, Waugh DJ, Gaivin RJ, Morilak D and Perez DM. (2000) Overexpression of the alpha1B-adrenergic receptor causes apoptotic neurodegeneration: multiple system atrophy. Nat. Med. 6: 1388-94 [PMID:11100125] 